Review

\title{
Genetic Testing for Antipsychotic Pharmacotherapy: Bench to Bedside
}

\author{
Mujeeb U. Shad 1,2,3
}

Citation: Shad, M.U. Genetic Testing for Antipsychotic Pharmacotherapy: Bench to Bedside. Behav. Sci. 2021, 11, 97. https://doi.org/10.3390/ bs11070097

Academic Editor: Valentina Echeverria

Received: 13 May 2021

Accepted: 23 June 2021

Published: 30 June 2021

Publisher's Note: MDPI stays neutral with regard to jurisdictional claims in published maps and institutional affiliations.

Copyright: (C) 2021 by the author. Licensee MDPI, Basel, Switzerland. This article is an open access article distributed under the terms and conditions of the Creative Commons Attribution (CC BY) license (https:// creativecommons.org/licenses/by/ $4.0 /)$.
1 Spring Valley Hospital and Medical Center, Valley Health System, Las Vegas, NV 89118, USA; mujeebushad@gmail.com

Department of Psychiatry, University of Nevada, Las Vegas, NV 89154, USA

College of Osteopathic Medicine, Touro University Nevada, Las Vegas, NV 89014, USA

\begin{abstract}
There is growing research interest in learning the genetic basis of response and adverse effects with psychotropic medications, including antipsychotic drugs. However, the clinical utility of information from genetic studies is compromised by their controversial results, primarily due to relatively small effect and sample sizes. Clinical, demographic, and environmental differences in patient cohorts further explain the lack of consistent results from these genetic studies. Furthermore, the availability of psychopharmacological expertise in interpreting clinically meaningful results from genetic assays has been a challenge, one that often results in suboptimal use of genetic testing in clinical practice. These limitations explain the difficulties in the translation of psychopharmacological research in pharmacogenetics and pharmacogenomics from bench to bedside to manage increasingly treatment-refractory psychiatric disorders, especially schizophrenia. Although these shortcomings question the utility of genetic testing in the general population, the commercially available genetic assays are being increasingly utilized to optimize the effectiveness of psychotropic medications in the treatment-refractory patient population, including schizophrenia. In this context, patients with treatment-refractory schizophrenia are among of the most vulnerable patients to be exposed to the debilitating adverse effects from often irrational and high-dose antipsychotic polypharmacy without clinically meaningful benefits. The primary objective of this comprehensive review is to analyze and interpret replicated findings from the genetic studies to identify specific genetic biomarkers that could be utilized to enhance antipsychotic efficacy and tolerability in the treatment-refractory schizophrenia population.
\end{abstract}

Keywords: genetic testing; antipsychotic; pharmacotherapy; schizophrenia

\section{Introduction}

Genetic testing is increasingly utilized to identify genetic biomarkers for optimizing the efficacy and tolerability of psychotropic drugs, especially antidepressants. However, genetic testing is also being requested to enhance the effectiveness of antipsychotic drugs, which is especially true for the treatment-refractory schizophrenia population, who frequently experience irrational polypharmacy at high dosages with significant adverse effects, generally without much therapeutic benefit. Currently, the most evidence in supporting genetic assays is based on pharmacogenetic (PG) studies, which utilize a candidate gene(s) approach investigating the effect(s) of genetic polymorphism(s) on efficacy, tolerability, and/or safety of antipsychotic drugs [1]. Most clinically meaningful findings have been reported using genetic factors affecting the pharmacokinetics (PKs) of antipsychotic drugs, such as genetic polymorphisms in the drug-metabolizing cytochrome-P450 (CYP) enzymes to identify and/or predict effective and tolerable dosages of an antipsychotic drug. In contrast, findings from PG studies investigating genetic variance in pharmacodynamic (PD) factors, such as transporters, neuropeptides, and receptors, have produced inconsistent results, which is most likely due to the small sample sizes (limiting sub-group 
analyses) resulting in small effect sizes, lack of control for confounding factors (affecting efficacy and/or tolerability), and medication nonadherence further compromising the results. Despite these limitations, PG studies investigating PD genetic factors may be helpful to enhance the effectiveness of antipsychotic drugs with more success in the treatment-refractory population. Compared to PG studies, pharmacogenomic (PGx) studies require much larger samples to explore all potential associations between the effectiveness of antipsychotic drugs and multiple genes of the molecular targets for the antipsychotic drugs. Although Genome-Wide Association Studies (GWAS) provide the first logical step to explore these associations, these studies can be significantly expensive, which explains their scarcity in psychiatry. The lack of optimal research explains difficulties in the clinical application of genetic findings from the bench to the bedside. This review is a comprehensive analysis of findings from a large number of positive and negative genetic studies to provide insights into specific genetic biomarkers that could be utilized to optimize antipsychotic efficacy and tolerability, especially in the treatment-refractory schizophrenia population. The review also offers a brief discussion of commercially available genetic assays and future research directions to enhance the clinical utility of genetic testing in psychiatry.

\section{Pharmacogenetic Studies}

The data from PG studies are clinically utilized at the individual level to predict and optimize the response to antipsychotic drugs while preventing or minimizing adverse events. A drug's response or tolerability can be affected by genetic polymorphisms in PK factors, which determine the concentration of a drug at its site(s) of action, and PD factors, which determine a drug's response or tolerability at its molecular targets. However, these distinctions are rather arbitrary, as changes in a drug's concentration at the site of action (i.e., PKs) are always associated with changes in a drug's efficacy and/or tolerability (i.e., PDs) at its site(s) of action. The following section will review the PK and PD genetic findings from the pharmacogenetic studies, followed by a brief discussion of pharmacogenomic studies, commercially available assays, and future directions.

\subsection{Pharmacokinetic (PK) Genetic Biomarkers}

Genetic variance in drug-metabolizing enzymes, such as CYP enzymes, represents most of the PK biomarkers. The genetic polymorphisms of CYP enzymes have produced one of the most replicated and clinically relevant findings in patients who develop adverse effects on routinely administered dosages of an antipsychotic drug. A similar statement cannot be made for antipsychotic efficacy, probably because there is no apparent relationship between plasma levels of an antipsychotic drug and antipsychotic response with the exception of clozapine. In this context, CYP2D6 is one of the most clinically relevant enzymes; despite making only $2 \%$ of all CYP enzymes in the liver, CYP2D6 is involved in the metabolism of about $25 \%$ of several commonly used psychotropic agents, including antipsychotic drugs [2,3]. About $6-10 \%$ of Caucasians and $1 \%$ of Asians are poor metabolizers [4]. Patients homozygous for wild-type alleles are known as normal or extensive metabolizers, and those homozygous or heterozygous for the dysfunctional allele are labeled as intermediate metabolizers. About $1-2 \%$ of Caucasians have multiple copies of functional alleles and are called ultra-rapid metabolizers [5,6]. As compared to extensive metabolizers, patients that are ultra-rapid metabolizers require higher doses and those who are intermediate metabolizers require lower doses of drugs that are substrates for this enzyme due to altered elimination. If antipsychotic doses are not corrected for this genetic variance, ultra-rapid metabolizers for CYP2D6 may experience decrease or loss in efficacy and poor metabolizers may develop higher levels of antipsychotic drugs resulting in adverse effects, such as extrapyramidal symptoms (EPS) and hyperprolactinemia [2]. Despite relatively small sample PG studies, multiple studies have shown a relationship between dysfunctional CYP2D6 variants and antipsychotic-induced EPS, especially tardive dyskinesia (TD) [7-21] (Table 1). However, these findings have not been supported in some ethnic groups, such as in Indian [22], Slovenian [23], and Japanese [24] populations. 
These differences may be explained by small sample sizes and a lower frequency of poor metabolizer alleles for CYP2D6 alleles in these ethnic groups as compared to Caucasians. Nevertheless, a meta-analysis revealed at least one dysfunctional CYP2D6 allele associated with TD and parkinsonian symptoms in patients with schizophrenia [25]. Interestingly, most of these PG studies reporting an association between antipsychotic drugs and EPS failed to show a significant correlation between CYP2D6 variants and the efficacy of antipsychotic drugs [3]. However, many studies have been small, and many have not been adequately powered to capture more subtle changes in efficacy compared to more clinically visible EPS.

Table 1. Genetic biomarkers for antipsychotic response and adverse effects.

\begin{tabular}{|c|c|c|c|c|c|}
\hline \multicolumn{6}{|c|}{ Antipsychotic Response } \\
\hline Gene & Polymorphism & Risk Allele & Functional Outcome & Clinical Outcome & Statistical Significance \\
\hline DRD2 & $\begin{array}{l}\text {-141C Ins/Del } \\
\text { (rs1799732) }\end{array}$ & Del & $\begin{array}{l}\text { Decreased DRD2 } \\
\text { expression }\end{array}$ & $\begin{array}{l}\text { Lower antipsychotic } \\
\text { response }\end{array}$ & $\begin{array}{c}\text { Odds ratio }=0.65 \\
95 \% \text { confidence } \\
\text { interval }=95 \% \mathrm{CI}: \\
0.43-0.97[26]\end{array}$ \\
\hline HTR1A & C-1019G & G & $\begin{array}{l}\text { Increased HTR1A } \\
\text { expression }\end{array}$ & $\begin{array}{l}\text { G/G homozygosity with } \\
\text { lesser negative symptom } \\
\text { improvement [27-30] }\end{array}$ & $p=0.003$ \\
\hline HTR2A & T-102-C (rs6313) & $\mathrm{C}$ & $\begin{array}{l}\text { Decreased HTR2A } \\
\text { expression }\end{array}$ & $\begin{array}{c}\text { C/C homozygosity with } \\
\text { lower antipsychotic } \\
\text { response }\end{array}$ & $\begin{array}{c}\text { Odds ratio }=0.61 \\
95 \% \text { confidence } \\
\text { interval }=0.43-8.5[31]\end{array}$ \\
\hline COMT & Val 158Met & Val & $\begin{array}{c}\text { Faster metabolism } \\
\text { resulting in lower levels } \\
\text { of dopamine }\end{array}$ & $\begin{array}{l}\text { Lower antipsychotic } \\
\text { response [32] }\end{array}$ & $\begin{array}{c}\text { Odds ratio }=1.37 \\
95 \% \text { confidence } \\
\text { interval = 1.02-1.85) }\end{array}$ \\
\hline \multicolumn{6}{|c|}{ Weight Gain } \\
\hline HTR2C & C-759T (rs3813929) & $\mathrm{C}$ & $\begin{array}{l}\text { Lesser expression of } \\
\text { HTR2C receptors [33] }\end{array}$ & $\begin{array}{l}>7 \% \text { weight gain over } \\
\text { baseline with } \mathrm{C} \text { allele }\end{array}$ & $\begin{array}{c}\text { Odds ratio }=1.64 ; \\
95 \% \text { confidence } \\
\text { interval = } 0.73-3.69 \text { in chronic } \\
\text { subjects }[34-37] ; \\
\text { Odds ratio }=5.40 \\
95 \% \text { confidence } \\
\text { interval = 2.08-14.01 during } \\
\text { early psychosis }[34-37] .\end{array}$ \\
\hline MC4R & Rs489693 & A & Unknown & $\begin{array}{l}\text { AA homozygotes gained } \\
\text { about } 3 \mathrm{~kg} \text { more weight } \\
\text { than other genotypes [38] }\end{array}$ & $\begin{array}{c}\text { Odds Ratio (95\% confidence } \\
\text { interval) }\end{array}$ \\
\hline \multicolumn{6}{|c|}{ Tardive Dyskinesia } \\
\hline CYP2D6 & $\begin{array}{c}\text { Presence of at least } \\
\text { one } \\
\text { dysfunctional alleles }\end{array}$ & $\begin{array}{c}\text { One of } \\
3,4,5,6, \text { or } \\
10 \text { alleles }\end{array}$ & $\begin{array}{l}\text { Decreased CYP2D6 } \\
\text { enzyme activity }\end{array}$ & $\begin{array}{l}\text { Increased risk for tardive } \\
\text { dyskinesia }\end{array}$ & 1.83 95\% CI: $1.09-3.08)$ [7-21] \\
\hline HTR2A & $\mathrm{T} 102 \mathrm{C}$ & $\mathrm{C}$ & $\begin{array}{c}\text { Decreased HTR2A } \\
\text { expression and binding }\end{array}$ & $\begin{array}{c}\text { Presence of tardive } \\
\text { dyskinesia }\end{array}$ & 1.64 95\% CI: 1.17-2.32 [39] \\
\hline DRD2 & Taq1A (rs1800497) & $\mathrm{C}, \mathrm{A} 2$ & $\begin{array}{l}\text { Increased DRD2 } \\
\text { receptors and binding }\end{array}$ & $\begin{array}{c}\text { Presence of tardive } \\
\text { dyskinesia }\end{array}$ & 1.30 95\% CI: 1.09-1.55 [40] \\
\hline \multicolumn{6}{|c|}{ Agranulocytosis } \\
\hline HLADQB1 & $\begin{array}{c}\mathrm{G} 6672 \mathrm{C} \\
(\mathrm{rs} 1133322494)\end{array}$ & G & ? autoimmune effect & $\begin{array}{c}\text { Clozapine } \\
\text { discontinuation due to } \\
\text { ANC }<500 \text { cells } / \mathrm{mm}^{3}\end{array}$ & Odds ratio = $16.9[41]$ \\
\hline
\end{tabular}

Deficient activity of CYP enzyme $1 A 2$ has also been associated with adverse effects due to an increase in plasma levels of antipsychotic drugs that are substrates for this enzyme, such as clozapine and olanzapine [21,42,43]. In contrast, patients with high inducibility of CYP1A2, as observed with smoking in some patients, may end up with subtherapeutic levels of clozapine and olanzapine [44]. One study associated genetic variance in CYP3A4 activity with the efficacy of risperidone, an antipsychotic drug [45], while other studies produced negative results $[19,22]$. However, polymorphism in a specific transporter, Pglycoprotein (also known as multiple drug resistance-1 (MDR1) or ATP-binding cassette subfamily B member1 gene [46]) has been correlated with efficacy as well as tolerability of risperidone [47] and clozapine [48]. 


\subsection{Pharmacodynamic (PD) Biomarkers}

\subsubsection{Antipsychotic Response}

Antipsychotic efficacy across different antipsychotic drugs has been strongly linked with genetic variance in dopamine-2 receptors (DRD2). More specifically, D2-141C Del and TaqI A2 allelic variants have been associated with the inadequate antipsychotic response across various ethnic groups [49-52]. A comprehensive metanalysis supported the relationship between $D 2-141 \mathrm{C}$ Del and TaqI A2 allelic variants and antipsychotic response [26] (Table 1). Polymorphisms of the promotor regions of DRD2, DRD3, and DRD4 have also been linked with antipsychotic efficacy [52-56]. Another biomarker repeatedly associated with antipsychotic efficacy is catechol-o-methyl transferase (COMT), which primarily metabolizes dopamine [57-60] (Table 1). This finding was also supported by a meta-analysis [32], which showed that patients with met/met homozygosity were more likely to respond to antipsychotic drugs, especially the newer ones.

Specific polymorphisms in serotonin receptors have also been linked with the antipsychotic response, especially serotonin-2A receptors (HRT2A) 102-C/C genotype, which was associated with reduced antipsychotic efficacy in Caucasian patients $[61,62]$ (Table 1). Another HTR2A genotype, 1438-A/A, has been correlated with antipsychotic response in various ethnic groups. Lack of antipsychotic efficacy and treatment resistance for negative symptoms were found in a French cohort with 5-HT2A -1438-A/A genotype [63]. In Algerian patients, $5-H T 2 A-1438-G$ allele was associated with psychotic relapse [64]. Another polymorphism in serotonin receptor, HTR1A (i.e., 5-HT1A -1019G), has been associated with lower antipsychotic efficacy in various ethnic groups [28-30]. The association between symptom reduction and guanine nucleotide-binding protein subunit beta-3 variant was reported in more than one study $[65,66]$. However, the correlation between the L allele of 5-HTT LPR (serotonin transporter-linked promoter region) and improvement in negative symptoms of schizophrenia was observed in one study [67], while two other studies were negative $[68,69]$. Although multiple other reports have also observed association between specific PD markers and antipsychotic efficacy, these findings are without replication and questionable clinical utility [70-79].

Some studies have examined the pharmacogenetics of commonly used antipsychotic drugs, such as clozapine, risperidone, and olanzapine. In this context, clozapine, which is still the gold standard in the management of treatment-refractory schizophrenia, is the most extensively studied antipsychotic drug. Several studies have examined dopamine receptor polymorphisms to explain clozapine's unique efficacy and have found replicated genetic variance in DRD1 [80,81], DRD2 [82,83], DRD3 [84,85], and DRD4 [86,87] to be associated with clozapine efficacy. However, results with DRD3 were not supported by a recent meta-analysis [88], while the findings with DRD4 were not replicated in other studies $[89,90]$. Association between clozapine's efficacy and genetic variance in the dopamine transporter protein (DAT) has been supported by one study [91] but not the other [55]. However, one of the most robust findings with clozapine has been the correlation between HTR2A polymorphisms and clozapine treatment outcomes [62,92-95]. The results with HTR2A variants 102-T/C and Tyr452 were also confirmed by a meta-analysis [31] (Table 1). A comprehensive review documented correlations between antipsychotic efficacy and lower expression of HTR2A variants $102-\mathrm{C}$ and $-1438-\mathrm{G}$, and decreased functioning of HTR2A variant Tyr452 [1]. Other serotonin mechanisms have also been linked with clozapine's efficacy, such as variance in serotonin-2C (HTR2C) receptors [96,97] and SLC6A4 (solute carrier family 6 member 4 serotonin transporter) [67,98]. A combinatorial genetic assay for three HTR2A variants (i.e., 452Tyr, 1438-G/A, and 102-T/C), two HTR2C variants (i.e., 330-GT/244-CT and Cys23Ser), and one SLC6A4 variant provides the best predictive model for clozapine response with $76.7 \%$ positive predictive value and $95 \%$ sensitivity $[97,98]$. Despite several studies producing negative results with polymorphisms in various serotonin targets $[67,99-107]$, the overall data support the critical role of the serotonin system in clozapine's efficacy. However, clozapine response has not been associated 
with genetic variance in other important clozapine-targeted receptors, such as adrenergic and glutamatergic receptors [108-110].

Risperidone is another second-generation antipsychotic drug, which has shown decreased antipsychotic efficacy in patients with DRD2 Ser311 [111] variant associated with the reduced response at DRD2 receptors [112]. On the other hand, the D2-241-A allele was associated with a greater antipsychotic response with risperidone than the $-241-G$ allele in two studies [113,114]. A catechol-o-methyl transferase (COMT) variant (i.e., Val 158Met) has also been associated with lower risperidone efficacy in two studies $[115,116]$ and a metanalysis [32] (Table 1) as has been associated with a serotonin receptor variant, HRT2A 102-C, in Chinese [117], Korean [118], and Japanese [119] patients, but not in Caucasians [1]. Nevertheless, this relationship between COMT variant and antipsychotic efficacy points towards the importance of dopamine levels in antipsychotic response. Risperidone efficacy has also been linked with variance in brain-derived neurotrophic factor $(B D N F)$ in two studies $[120,121]$. However, unlike clozapine, no correlation was reported between risperidone response and $D R D 4$ variance [122]. Other genetic findings with risperidone have been in single studies and will not be reviewed here $[28,53,113,119,123-129]$. The findings from these single studies need to be replicated to be clinically relevant.

Olanzapine is another commonly used second-generation antipsychotic drug with reports of an association between its efficacy and DRD3 variant D3Ser9Gly [130,131], which has also been associated with antipsychotic efficacy of risperidone and clozapine $[130,131]$. However, this finding was not replicated in Indian patients [132], suggesting ethnic differences in response. Unlike risperidone, genetic variance in COMT was associated with olanzapine's efficacy in only one study [133]. In terms of serotonergic mechanisms, none of the findings with variance in the L allele of the 5-HTT LPR [134] and HTR6 polymorphisms [135] associated with olanzapine's efficacy have been replicated. However, once again, this olanzapine response was not associated with HRT2A and HRT2C variants in the Indian population [131,132], highlighting the ethnic differences in antipsychotic response. Glutamate metabotropic receptor-3 polymorphism [136] associated with better olanzapine response in only one study, a positive olanzapine's response with calcium channel variant, calcium voltage-gated channel subunit alpha1 C, rs1006737 was replicated in two studies [137,138].

Although aripiprazole is classified as one of the newer second-generation antipsychotic drugs, it is the first antipsychotic drug with partial agonist activity at D2 receptors and 5HT1A receptors [139]. A couple of studies have documented an association between D2 TaqI variants and the efficacy of aripiprazole in Korean and Chinese patients $[140,141]$. In summary, there is inadequate genetic data to compare clinically meaningful differences in genetically mediated antipsychotic response between different antipsychotic drugs, perhaps with the exception of clozapine.

\subsubsection{Antipsychotic Adverse Effects}

The genetic data for antipsychotic tolerability is not as consistent as those for antipsychotic efficacy, except for weight gain. The margin for controversial results is much higher than those from the efficacy studies, as documented below.

\section{Extrapyramidal Symptoms (EPS)}

Although genetic polymorphisms in CYP enzymes are grouped under PK biomarkers, it is worth mentioning here that any change in a drug's metabolism will eventually be expressed pharmacodynamically. Thus, the poor metabolizers for CYP2D6 have a higher risk for developing EPS due to increased plasma levels of antipsychotic drugs that are CYP2D6 substrates [7-21] (Table 1). However, the relationship between D2Rs polymorphisms and the development of EPS remains unclear [40]. Although some studies have found a correlation between DRD2 variants and EPS [142-145], many others have not [19,146-155]. Nevertheless, a metanalysis did report a significant correlation between DRD2 polymorphism (i.e., TAq1A) and TD [40] (Table 1). The results examining rela- 
tionship between EPS and DRD3 polymorphisms are also controversial; some studies supported the relationship [19,147,150,156-163], but some did not [143,147,150,164-167], while some strangely reported paradoxical results [168-170]. One study found an interaction between DRD3 and CYP 17A1 genotypes and EPS [158]. Another study reported no correlation between variance in DRD1 and EPS [155]. A couple of studies found a direct association between two variants of dopamine metabolizing enzyme, COMT (G158A and A-278G) and risk for TD [148,171]. However, results were negative with another COMT variant, Val158Met [146,172-174]. No associations were reported with genetic variance in other dopamine targets, such as dopamine transporter-1 (DAT1) [146,147,175] and polymorphisms of dopamine-related enzymes, monoamine oxidase A, and monoamine oxidase B [146,174]. The relationship between the regulator of the G-protein signaling 2 gene and pseudo-parkinsonian symptoms was supported in Caucasian $[176,177]$ as well as in Japanese [178] patients.

Genetic variance in the serotonergic system has also produced inconsistent results; some reports have documented associations between HRT2A polymorphisms and TD $[150,170,179,180]$, and some have not $[143,172,181,182]$. However, pooled data from 635 patients reported a correlation between the HRT2A 102-C allele and age-related increase in risk for TD [39] (Table 1). A link between TD and HRT2C variant Cys23Ser was supported by several studies [143,163,183-185], but not all [109,143,163,181]. In addition, no relationship was discovered between EPS and HRT2A or serotonin transporter (SLC6A4) gene variants $[172,186,187]$. Although three studies linked polymorphism in the brain-derived neurotrophic factor (BDNF) gene with the risk of TD [120,165,188], one study produced negative results [168]. Polymorphism in a p-glycoprotein transporter gene, ATP-binding cassette sub-family B member 1 (ABCB1), was only marginally associated with dystonia and akathisia [189]. No clear associations were observed between EPS and genes involved in oxidation and stress, such as manganese superoxide dismutase [190-192], nitric oxide synthase [193-195], glutathione S-transferase [196], and glutathione peroxidase [197]. Only marginal associations were reported with polymorphism in nicotinamide adenine dinucleotide phosphate (NADPH), dehydrogenase quinone, nitric oxide synthase 3 [198,199], and glutathione S-transferase $\mu 1$ [19]. Polymorphisms in angiotensin I converting enzyme [156] and protein kinase B [200] were not found to correlate with EPS as well. However, in one study, EPS were associated with polymorphism in adrenergic type 1A receptors [201]. Despite inconsistent results from reviewed studies, the overall data do support an important role for dopamine and serotonin systems in the development of antipsychotic drugs-induced EPS.

\section{Hyperprolactinemia}

Although there is not much research investigating the role of genetic variance on antipsychotic-induced hyperprolactinemia, any DRD2 polymorphism that increases the risk for EPS will also increase the risk for hyperprolactinemia, as both adverse effects are mediated by D2R blockade. In this context, one study did report $40 \%$ higher prolactin levels in patients with DRD2*A1 allele than those without [202]. Interestingly, this increase in prolactin was also observed with clozapine, which is least likely to increase prolactin levels [202].

\section{Weight Gain and Metabolic Syndrome}

Serotonin is one of the main neurotransmitter systems that control feeding behavior in the hypothalamus and is targeted by the second-generation antipsychotic drugs via their blocking effects on 5HT2C receptors [203]. Although the genetic mechanisms underlying weight gain due to HTR2C polymorphisms are not completely clear, several HRT2C gene haplotypes have been associated with weight gain and metabolic syndrome [34-37]. Haplotype A (-997G, -759C, -697G) was the most robustly associated haplotype with antipsychotic-induced weight gain. In contrast, presence of haplotype B (-997A, -759T, -697C) was found to be protective against antipsychotic-induced weight gain [204-210] 
(Table 1). One of these haplotypes, B (i.e., -759T), has been associated with decreased expression of 5HT2C receptors [33]. Increased negative feedback due to increased levels of leptin observed in patients with haplotype B may explain the resistance against weight gain [27]. Interestingly this weight resistance with haplotype B was not observed in younger patients [211]. Although a meta-analysis revealed a $100 \%$ increase in risk for weight gain in patients with HRT2C -759 C allele [212], there were studies that did not find any correlation between the presence of the -759 C allele and weight gain [213-217]. In addition, no relationship was observed between weight gain and another HRT2C polymorphism, Cys23Ser [212,218,219]. Genetic variance in other serotonin receptors, such as HRT2A 102-T/C, have also been associated with weight gain, obesity, and lipid levels [34,220,221], except one study [219]. No association was documented with a HRT1A polymorphism [220]. Finally, a short allele of the serotonin transporter gene (i.e., 5-HTT LPR) was significantly associated with weight gain and obesity in the Caucasian population [134,221], but not in Chinese patients [219].

Although earlier studies did find an association between weight gain and genetic variance in DRD2 [220,222] or DRD3 [220], one recent study did observe a positive relationship between weight gain and DRD2 variants rs6277 (C957T), rs1079598, and rs1800497 (TaqIA) [223]. In addition, a functional promoter region variant in DRD2 was implicated in a study of antipsychotic drug-induced weight gain during early psychosis with minimal prior exposure to antipsychotic drugs [224]. Carriers of -141C Ins/Del in the DRD2 promoter gene demonstrated substantially more weight gain than noncarriers after 6 weeks of treatment with risperidone or olanzapine. Another study reported an association between an increase in body mass index and a DRD4 variable number tandem repeat allele during antipsychotic treatment [218].

Few studies have reported a significant correlation between genetic polymorphism in melanocortin 4 receptors (MC4R) and antipsychotic-induced weight gain $[225,226]$, which is also supported by a genome-wide association study [38] (Table 1). Several studies have reported involvement of the adrenergic receptor $2 \mathrm{~A}$ in treatment-related weight gain, although with differential effects across various ethnic groups [227-229]. Genetic variance in other adrenergic receptors, such as 5HT1A, have also been associated with changes in body mass index [230]. Leptin appears to play an important role in mediating antipsychotic drug-induced weight gain, as reflected by the association between a leptin gene variant, $-2548-\mathrm{A} / \mathrm{G}$, and weight gain, despite the different direction of these results [209,216,231-233]. Results with leptin studies were also inconclusive across various ethnic groups, such as Indians [171] and Germans [37]. Interestingly, this leptin variant was not associated with weight gain in patients with premorbid obesity [234]. One study also found a correlation between a leptin receptor polymorphism and weight gain [234].

One study reported a correlation between antipsychotic-induced weight gain and polymorphism in insulin-induced gene 2 [235], but a couple of other studies did not $[37,236]$. Similarly, the association between guanine nucleotide-binding protein subunit beta-3 polymorphism and weight gain in Indians [132] was not replicated in other ethnic groups, such as Koreans [237], Taiwanese [238], and Caucasians [239]. One study failed to find any association between the histamine-1 receptor gene and antipsychotic-induced weight gain [240]. Results were also negative with the cholecystokinin gene [241]. However, associations have been reported between weight gain and/or metabolic syndrome and apolipoprotein E [242], brain-derived neurotrophic factor [220,243], cannabinoid receptor1 [244], CYP2D6 [220,245], multidrug resistance 1 [217], methylenetetrahydrofolate reductase [246,247], peroxisome proliferator-activated receptor- $\gamma$ [248], synaptosomal-associated protein 25 [249], and tumor necrosis factor [250,251].

\section{Agranulocytosis}

Agranulocytosis is a rare but severe and potentially lethal adverse effect associated with clozapine use. Pharmacogenetic studies have reported strong associations between polymorphisms in the major histocompatibility complex and clozapine-induced agran- 
ulocytosis [252-254]. Two cohorts from a clozapine study found significantly high odds ratios (16.9) for agranulocytosis in patients with a human leukocyte antigen (HLA)-DQB1, which is a single-nucleotide polymorphism (i.e., 6672G $>$ C) with high specificity and sensitivity rates [41] (Table 1). Another study proposed that the patients with a history of clozapine-induced granulocytopenia but without the variant HLA-B*59:01 may be successfully re-challenged with clozapine [255]. However, similar to results from the genetic studies investigating antipsychotic-induced TD, involvement of oxidative genes in bone marrow toxicity has also produced inconsistent results, as reflected by a marginal association with NADPH quinone 2 (NQO2) polymorphism [256] and negative results with myeloperoxidase $[257,258]$. An association with clozapine-induced agranulocytosis was also reported with tumor necrosis factor [259] but not with cytochrome b-245 $\alpha$ polypeptide [257] or with CYPD26 [258] variants.

\section{Pharmacogenomic (PGx) Studies}

These studies have primarily explored the effects of genetically mediated PD differences in a drug's response and/or adverse effects through a systematic assessment of genes, their products, and individual variation in gene expression and function. In this context, GWAS are most useful to generate hypotheses that can be later confirmed in future studies. These studies explore associations between multiple genes and psychotropic drugs [260]; therefore, they require large cohorts associated with high costs, which explains the scarcity of these studies with psychotropic medications. This may be the reason why most GWAS studies with antipsychotic drugs are primarily based on post hoc analyses from a large effectiveness trial, CATIE (Clinical Antipsychotic Trials of Intervention Effectiveness) [261-265]. Polymorphisms in the ankyrin repeat and sterile $\alpha$ motif domain containing $1 \mathrm{~B}$ (ANKS1B) and contactin-associated protein-like 5 were linked to the efficacy of olanzapine and risperidone in terms of negative symptoms [265]. In addition, earlier GWAS identified genes from a region in chromosome 12 that were associated with antipsychotic-induced weight gain [266], GABAergic genes related to drug-induced TD [267], and HLA B*59:01 correlated with clozapine-induced agranulocytosis [255]. Another GWAS found 20 statistically significant polymorphisms at a single locus near the melanocortin 4 receptor $(M C 4 R)$ gene associated with weight gain in patients undergoing the first trial with antipsychotic drugs, which is consistent with a region previously identified by large-scale GWAS of obesity in the general population [38]. These data implicate MC4R in extreme SGA-induced weight gain and related metabolic disturbances. Most recently, polygenic risk scores derived from significantly associated SNPs with schizophrenia patients of European ancestry were found to inversely correlate with the antipsychotic response [268]. It will be interesting to see if these results become more significant in specific sub-group analyses, such as males versus females, age at onset, and European versus non-European samples [268].

Antipsychotic treatment in a subset of 738 schizophrenia patients from the CATIE study [264] polymorphisms localized within or close to the genes, ETS homologous factor, solute carrier family 26 member 9 (SLC26A9), DRD2, G protein-coupled receptor 137B, carbohydrate sulfotransferase 8 , and interleukin1-alpha (IL1A) was associated with improvements in various neurocognitive domain areas. A significant result was also found for the variant rs286913 in the ETS homologous factor related to the effects of ziprasidone on vigilance. Furthermore, the presence of rs11240594 in the SLC26A9 gene and rs11677416 in the IL1A gene was linked to olanzapine-induced improvement in processing speed and working memory.

\section{Commercially Available Genetic Assays}

These assays offer genetic testing for multiple genetic biomarkers (combinatorial assays) for treatment response and/or tolerability identified in other studies to facilitate the selection of effective psychotropic medications. The clinical utility of these combinatorial genetic assays has primarily been tested in underpowered and open-label studies. Thus, these assays with specific panels for different groups of psychotropic drugs are based 
on findings from other studies using a candidate gene(s) approach. Although there is no specific genetic assay for antipsychotic drugs, combinatorial genotyping of genetic biomarkers is used to optimize the efficacy and tolerability of antipsychotic drugs, especially in the treatment-refractory population. In this context, genetic variance in PK biomarkers (primarily the CYP enzyme system) has been clinically helpful to optimize antipsychotic treatment. Most genetically relevant CYP enzyme assays for antipsychotic drugs include CYP1A2, CYP2D6, and CYP2C19. AmpliChip ${ }^{\mathrm{TM}}$ is the only FDA-approved genetic test, which is a microarray-based product to assess the activity of CYP2D6 and CYP2C19 and can be helpful in a large number of psychiatric patients as multiple psychotropic drugs are metabolized by these two CYP enzymes. Genetic testing for CYP2D6 is among the most clinically relevant investigation, as several important psychotropic drugs, including antipsychotic drugs, such as haloperidol, perphenazine, and risperidone, are metabolized by this enzyme. Following are the major resources and genetic assay companies that offer genetic testing for psychotropic drugs.

The GeneSight ${ }^{\circledR}$ (Myriad Health ${ }^{\circledR}$, South San Francisco, CA, USA) combinatorial assays provide coverage for about $50 \mathrm{PK}$ alleles, including those for CYP2D6, CYP2C19, CYP2C9, CYP2B6, CYP3A4, and CYP1A2, and some PD genes (5HTT, HTR2A, COMT, CACNA1C, MTHFR). On the basis of information on these genetic biomarkers, an individualized report is created which divides psychotropic medications into a green bin for recommended use, a yellow bin for use with caution, and a red bin use with extreme caution and frequent monitoring.

Genecept ${ }^{\mathrm{TM}}$ assay $\left(\right.$ Genomind $^{\circledR}$ ) also provides testing for PK biomarkers (CYP2D6, CYP2C19, CYP3A4) and PD markers, (5HT transporter, 5HT2C receptors, DRD2, COMT, CACNA1C, ANK3, and MTHFR). Like the GeneSight report, each patient's results are provided to the ordering clinician, along with suggested therapeutic options.

Drug-Metabolizing Enzymes and Transporters (DMET ${ }^{\mathrm{TM}}$ ) Plus Solution is one of the largest commercially available genetic assays for about 2000 PK variants across multiple genes. The DMET TMPlus Solution was developed as a platform to identify genetic variance and has not been tested for its efficacy in enhancing clinical outcomes with psychotropic drugs.

\section{Future Directions}

One of the most important goals for future genetic research in psychopharmacology will be to replicate and validate results from small sample genetic studies to resolve inconsistent results. However, these goals can only be accomplished by large, prospective, well-conducted multisite clinical trials such as genome-wide association studies to allow subgroup analyses and provide control for demographic, clinical, and environmental factors while close monitoring for medication adherence. In this context, the clinical trial network model used in oncology and cardiology has already been initiated in psychiatry, including Implementing Genomics in Practice (IGNITE), the Dutch Pharmacogenetics Working Group, and the Pharmacogenomic Resource for Enhanced Decisions in Care and Treatment. These large-scale initiatives will offer an effective tool to explore the relationship between efficacy and tolerability of various antipsychotic drugs and multiple genetic variants to generate hypotheses that could be tested in hypothesis-driven randomized controlled trials to improve and expand on currently available genetic biomarkers. A minimum set of genes and alleles is required for consistent pharmacogenomic decisionmaking before combinatorial genetic assays can be used beyond the treatment-refractory population. With the growing research in this area, it is only a matter of time that these efforts will help develop comprehensive combinatorial commercially available assays and toolkits with clinical utility beyond the treatment-refractory patient population facilitating the application of bench research to the clinical bedside. Equally importantly, clinicians must be trained and updated to enhance clinical application and interpretation of results from the existing and ongoing genetic studies with psychotropic medications, including antipsychotic drugs. 
Funding: This research received no external funding.

Institutional Review Board Statement: Not applicable.

Informed Consent Statement: Not applicable.

Conflicts of Interest: The authors declare no conflict of interest.

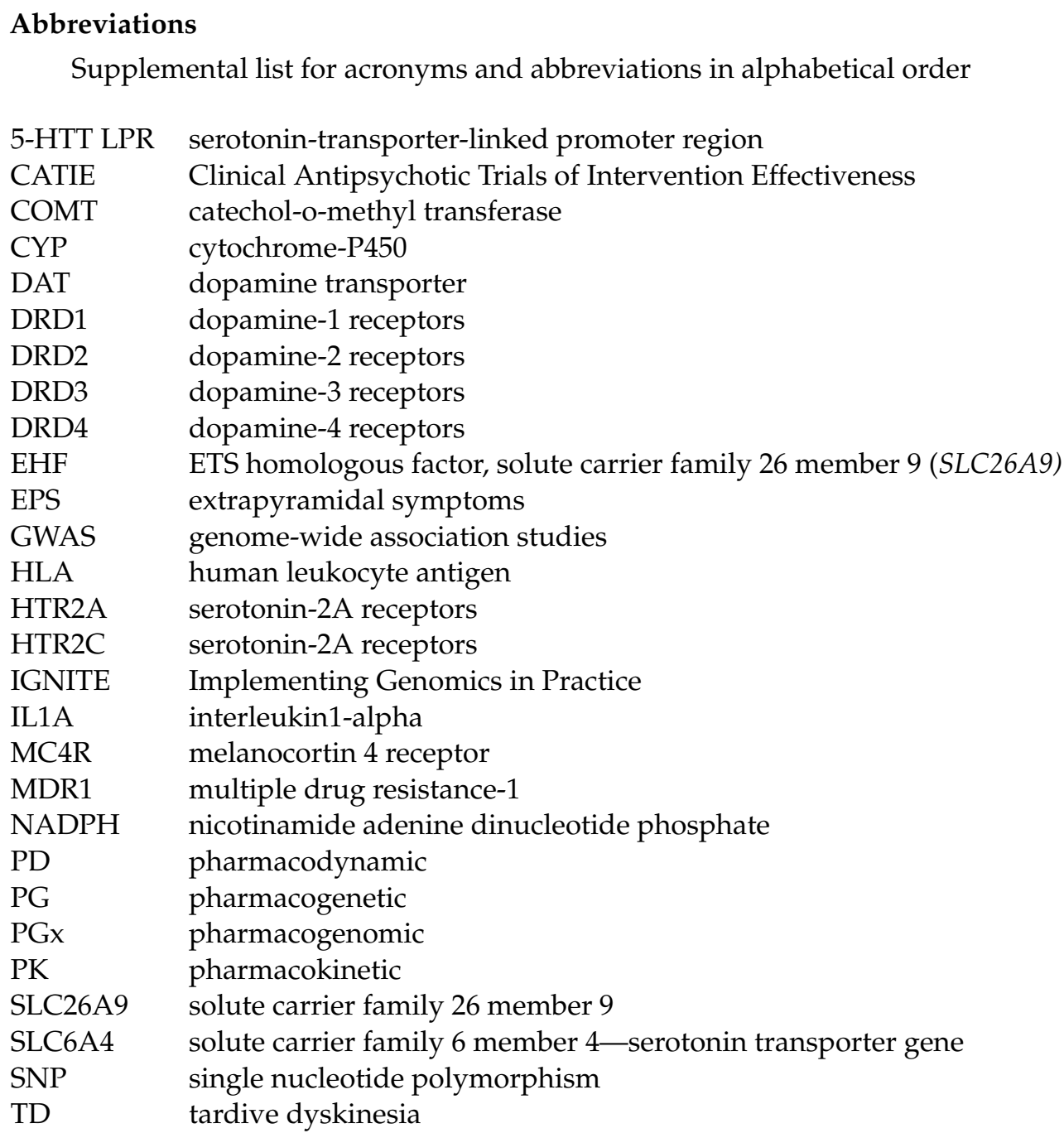

\section{References}

1. Arranz, M.J.; de Leon, J. Pharmacogenetics and pharmacogenomics of schizophrenia: A review of last decade of research. Mol. Psychiatry 2007, 12, 707-747. [CrossRef] [PubMed]

2. Crescenti, A.; Mas, S.; Gasso, P.; Parellada, E.; Bernardo, M.; Lafuente, A. Cyp2d6*3, ${ }^{*} 4{ }^{*} 5$ and ${ }^{*} 6$ polymorphisms and antipsychoticinduced extrapyramidal side-effects in patients receiving antipsychotic therapy. Clin. Exp. Pharmacol. Physiol. 2008, 35, 807-811. [CrossRef] [PubMed]

3. Ravyn, D.; Ravyn, V.; Lowney, R.; Nasrallah, H.A. CYP450 pharmacogenetic treatment strategies for antipsychotics: A review of the evidence. Schizophr. Res. 2013, 149, 1-14. [CrossRef] [PubMed]

4. Cai, W.M.; Chen, B.; Zhang, W.X. Frequency of CYP2D6*10 and *14 alleles and their influence on the metabolic activity of CYP2D6 in a healthy Chinese population. Clin. Pharmacol Ther. 2007, 81, 95-98. [CrossRef] [PubMed]

5. Demirtas, D.; Sumbul, H.E.; Bulut, A.; Demirtas, A.O.; Gulumsek, E.; Koca, H.; Icen, Y.K.; Koc, M. Tp-e interval, Tp-e/QT and Tp-e/QTc ratio in hypertensive patients with primary aldosteronism. Clin. Exp. Hypertens. 2020, 42, 93-98. [CrossRef]

6. Gasche, Y.; Daali, Y.; Fathi, M.; Chiappe, A.; Cottini, S.; Dayer, P.; Desmeules, J. Codeine intoxication associated with ultrarapid CYP2D6 metabolism. N. Engl. J. Med. 2004, 351, 2827-2831. [CrossRef]

7. Arthur, H.; Dahl, M.L.; Siwers, B.; Sjoqvist, F. Polymorphic drug metabolism in schizophrenic patients with tardive dyskinesia. J. Clin. Psychopharmacol. 1995, 15, 211-216. [CrossRef] [PubMed] 
8. Andreassen, O.A.; MacEwan, T.; Gulbrandsen, A.K.; McCreadie, R.G.; Steen, V.M. Non-functional CYP2D6 alleles and risk for neuroleptic-induced movement disorders in schizophrenic patients. Psychopharmacology 1997, 131, 174-179. [CrossRef]

9. Armstrong, M.; Daly, A.K.; Blennerhassett, R.; Ferrier, N.; Idle, J.R. Antipsychotic drug-induced movement disorders in schizophrenics in relation to CYP2D6 genotype. Br. J. Psychiatry 1997, 1702, 3-26. [CrossRef] [PubMed]

10. Kapitany, T.; Meszaros, K.; Lenzinger, E.; Schindler, S.D.; Barnas, C.; Fuchs, K.; Sieghart, W.; Aschauer, H.N.; Kasper, S. Genetic polymorphisms for drug metabolism (CYP2D6) and tardive dyskinesia in schizophrenia. Schizophr. Res. 1998, 32, 101-106. [CrossRef]

11. Scordo, M.G.; Spina, E.; Romeo, P.; Dahl, M.L.; Bertilsson, L.; Johansson, I.; Sjoqvist, F. CYP2D6 genotype and antipsychoticinduced extrapyramidal side effects in schizophrenic patients. Eur. J. Clin. Pharmacol. 2000, 56, 679-683. [CrossRef] [PubMed]

12. Lam, L.C.; Garcia-Barcelo, M.M.; Ungvari, G.S.; Tang, W.K.; Lam, V.K.; Kwong, S.L.; Lau, B.S.; Kwong, P.P.; Waye, M.M.; Chiu, H.F. Cytochrome P450 2D6 genotyping and association with tardive dyskinesia in Chinese schizophrenic patients. Pharmacopsychiatry 2001, 34, 238-241. [CrossRef] [PubMed]

13. Ellingrod, V.L.; Schultz, S.K.; Arndt, S. Abnormal movements and tardive dyskinesia in smokers and nonsmokers with schizophrenia genotyped for cytochrome P450 2D6. Pharmacotherahy 2002, 22, 1416-1419. [CrossRef] [PubMed]

14. Jaanson, P.; Marandi, T.; Kiivet, R.A.; Vasar, V.; Vaan, S.; Svensson, J.O.; Dahl, M.L. Maintenance therapy with zuclopenthixol decanoate: Associations between plasma concentrations, neurological side effects and CYP2D6 genotype. Psychopharmacology 2002, 162, 67-73. [CrossRef]

15. Nikoloff, D.; Shim, J.C.; Fairchild, M.; Patten, N.; Fijal, B.A.; Koch, W.H.; MacPherson, A.; Flockhart, D.; Yoon, Y.R.; Yoon, J.S.; et al. Association between CYP2D6 genotype and tardive dyskinesia in Korean schizophrenics. Pharm. J. 2020, 2, 400-407. [CrossRef] [PubMed]

16. Inada, T.; Senoo, H.; Iijima, Y.; Yamauchi, T.; Yagi, G. Cytochrome P450 II D6 gene polymorphisms and the neuroleptic-induced extrapyramidal symptoms in Japanese schizophrenic patients. Psychiatr. Genet. 2003, 13, 163-168. [CrossRef]

17. Lohmann, P.L.; Bagli, M.; Krauss, H.; Müller, D.J.; Schulze, T.G.; Fangerau, H.; Ludwig, M.; Barkow, K.; Held, T.; Heun, R.; et al. CYP2D6 polymorphism and tardive dyskinesia in schizophrenic patients. Pharmacopsychiatry 2003, 36, 73-78. [CrossRef] [PubMed]

18. Liou, Y.J.; Wang, Y.C.; Bai, Y.M.; Lin, C.C.; Yu, S.C.; Liao, D.L.; Lin, M.W.; Chen, J.Y.; Lai, I.C. Cytochrome P-450 2D6*10 C188T polymorphism is associated with antipsychotic-induced persistent tardive dyskinesia in Chinese schizophrenic patients. Neuropsychobiology 2004, 49, 167-173. [CrossRef]

19. de Leon, J.; Susce, M.T.; Pan, R.M.; Koch, W.H.; Wedlund, P.J. Polymorphic variations in GSTM1, GSTT1, PgP, CYP2D6, CYP3A5, and dopamine $\mathrm{D}_{2}$ and $\mathrm{D}_{3}$ receptors and their association with tardive dyskinesia in severe mental illness. J. Clin. Psychopharmacol. 2005, 25, 448-456. [CrossRef]

20. Patsopoulos, N.A.; Ntzani, E.E.; Zintzaras, E.; Ioannidis, J.P. CYP2D6 polymorphisms and the risk of tardive dyskinesia in schizophrenia: A meta-analysis. Pharmacogenet. Genom. 2005, 15, 151-158. [CrossRef]

21. Fu, Y.; Fan, C.H.; Deng, H.H.; Hu, S.H.; Lv, D.P.; Li, L.H.; Wang, J.J.; Lu, X.Q. Association of CYP2D6 and CYP1A2 gene polymorphism with tardive dyskinesia in Chinese schizophrenic patients. Acta Pharmacol. Sin. 2006, 27, 328-332. [CrossRef]

22. Tiwari, A.K.; Deshpande, S.N.; Rao, A.R.; Bhatia, T.; Lerer, B.; Nimgaonkar, V.L.; Thelma, B.K. Genetic susceptibility to tardive dyskinesia in chronic schizophrenia subjects: III. Lack of association of CYP3A4 and CYP2D6 gene polymorphisms. Schizophr. Res. 2005, 75, 21-26. [CrossRef] [PubMed]

23. Plesnicar, B.K.; Zalar, B.; Breskvar, K.; Dolzan, V. The influence of the CYP2D6 polymorphism on psychopathological and extrapyramidal symptoms in the patients on long-term antipsychotic treatment. J. Psychopharmacol. 2006, 20, 829-833. [CrossRef] [PubMed]

24. Kakihara, S.; Yoshimura, R.; Shinkai, K.; Matsumoto, C.; Goto, M.; Kaji, K.; Yamada, Y.; Ueda, N.; Ohmori, O.; Nakamura, J. Prediction of response to risperidone treatment with respect to plasma concencentrations of risperidone, catecholamine metabolites, and polymorphism of cytochrome P450 2D6. Int. Clin. Psychopharmacol. 2005, 20, 71-78. [CrossRef] [PubMed]

25. Fleeman, N.; Dundar, Y.; Dickson, R.; Jorgensen, A.; Pushpakom, S.; McLeod, C.; Pirmohamed, M.; Walley, T. Cytochrome P450 testing for prescribing antipsychotics in adults with schizophrenia: Systematic review and meta-analyses. Pharm. J. 2011, 11, 1-14. [CrossRef]

26. Zhang, J.P.; Lencz, T.; Malhotra, A.K. $\mathrm{D}_{2}$ receptor genetic variation and clinical response to antipsychotic drug treatment: A meta-analysis. Am. J. Psychiatry 2010, 167, 763-772. [CrossRef]

27. Reynolds, G.P.; Hill, M.J.; Kirk, S.L. The 5-HT2C receptor and antipsychoticinduced weight gain-mechanisms and genetics. J. Psychopharmacol. 2006, 20, 15-18. [CrossRef]

28. Wang, L.; Fang, C.; Zhang, A.; Du, J.; Yu, L.; Ma, J.; Feng, G.; Xing, Q.; He, L. The -1019 C/G polymorphism of the 5-HT(1)A receptor gene is associated with negative symptom response to risperidone treatment in schizophrenia patients. J. Psychopharmacol. 2008, 22, 904-909. [CrossRef]

29. Reynolds, G.P.; Arranz, B.; Templeman, L.A.; Fertuzinhos, S.; San, L. Effect of 5-HT1A receptor gene polymorphism on negative and depressive symptom response to antipsychotic treatment of drug-naive psychotic patients. Am. J. Psychiatry 2006, 163, 1826-1829. [CrossRef] 
30. Mössner, R.; Schuhmacher, A.; Kühn, K.U.; Cvetanovska, G.; Rujescu, D.; Zill, P.; Quednow, B.B.; Rietschel, M.; Wölwer, W.; Gaebel, W.; et al. Functional serotonin 1A receptor variant influences treatment response to atypical antipsychotics in schizophrenia. Pharm. Genom. 2009, 19, 91-94. [CrossRef]

31. Arranz, M.J.; Munro, J.; Sham, P.; Kirov, G.; Murray, R.M.; Collier, D.A.; Kerwin, R.W. Meta-analysis of studies on genetic variation in 5-HT2A receptors and clozapine response. Schizophr. Res. 1998, 32, 93-99. [CrossRef]

32. Huang, E.; Zai, C.C.; Lisoway, A.; Maciukiewicz, M.; Felsky, D.; Tiwari, A.K.; Bishop, J.R.; Ikeda, M.; Molero, P.; Ortuno, F.; et al. Catechol-O-Methyltransferase Val158Met Polymorphism and Clinical Response to Antipsychotic Treatment in Schizophrenia and Schizo-Affective Disorder Patients: A Meta-Analysis. Int. J. Neuropsychopharmacol. 2016, 19, pyv132. [CrossRef]

33. Buckland, P.R.; Hoogendoorn, B.; Guy, C.A.; Smith, S.K.; Coleman, S.L.; O’Donovan, M.C. Low gene expression conferred by association of an allele of the 5-HT2C receptor gene with antipsychotic-induced weight gain. Am. J. Psychiatry 2005, 162, 613-615. [CrossRef]

34. Gunes, A.; Melkersson, K.I.; Scordo, M.G.; Dahl, M.L. Association between HTR2C and HTR2A polymorphisms and metabolic abnormalities in patients treated with olanzapine or clozapine. J. Clin. Psychopharmacol. 2009, 29, 65-68. [CrossRef]

35. Mulder, H.; Franke, B.; van der-Beek, A.A.; Arends, J.; Wilmink, F.W.; Scheffer, H.; Egberts, A.C. The association between HTR2C gene polymorphisms and the metabolic syndrome in patients with schizophrenia. J. Clin. Psychopharmacol. 2007, 27, 338-343. [CrossRef]

36. Mulder, H.; Cohen, D.; Scheffer, H.; Gispen-de Wied, C.; Arends, J.; Wilmink, F.W.; Franke, B.; Egberts, A.C. HTR2C gene polymorphisms and the metabolic syndrome in patients with schizophrenia: A replication study. J. Clin. Psychopharmacol. 2009, 29, 16-20. [CrossRef]

37. Opgen-Rhein, C.; Brandl, E.J.; Muller, D.J.; Neuhaus, A.H.; Tiwari, A.K.; Sander, T.; Dettling, M. Association of HTR2C, but not LEP or INSIG2, genes with antipsychotic-induced weight gain in a German sample. Pharmacogenomics 2010, 11, 773-780. [CrossRef] [PubMed]

38. Malhotra, A.K.; Correll, C.U.; Chowdhury, N.I.; Müller, D.J.; Gregersen, P.K.; Lee, A.T.; Tiwari, A.K.; Kane, J.M.; Fleischhacker, W.W.; Kahn, R.S.; et al. Association between common variants near the melanocortin 4 receptor gene and severe antipsychotic drug-induced weight gain. Arch. Gen. Psychiatry 2012, 69, 904-912. [CrossRef] [PubMed]

39. Lerer, B.; Segman, R.H.; Tan, E.C.; Basile, V.S.; Cavallaro, R.; Aschauer, H.N.; Strous, R.; Chong, S.A.; Heresco-Levy, U.; Verga, M.; et al. Combined analysis of 635 patients confirms an age-related association of the serotonin 2A receptor gene with tardive dyskinesia and specificity for the non-orofacial subtype. Int. J. Neuropsychopharmacol. 2005, 8, 411-425. [CrossRef]

40. Zai, C.C.; De Luca, V.; Hwang, R.W.; Voineskos, A.; Muller, D.J.; Remington, G.; Kennedy, J.L. Meta-analysis of two dopamine D2 receptor gene polymorphisms with tardive dyskinesia in schizophrenia patients. Mol. Psychiatry 2007, 12, 794-795. [CrossRef] [PubMed]

41. Athanasiou, M.C.; Dettling, M.; Cascorbi, I.; Mosyagin, I.; Salisbury, B.A.; Pierz, K.A.; Zou, W.; Whalen, H.; Malhotra, A.K.; Lencz, T.; et al. Candidate gene analysis identifies a polymorphism in HLA-DQB1 associated with clozapine-induced agranulocytosis. $J$. Clin. Psychiatry 2011, 72, 458-463. [CrossRef]

42. Basile, V.S.; Ozdemir, V.; Masellis, M.; Walker, M.L.; Meltzer, H.Y.; Lieberman, J.A.; Potkin, S.G.; Alva, G.; Kalow, W.; Macciardi, F.M.; et al. A functional polymorphism of the cytochrome P450 1A2 (CYP1A2) gene: Association with tardive dyskinesia in schizophrenia. Mol. Psychiatry 2000, 5, 410-417. [CrossRef] [PubMed]

43. Tiwari, A.K.; Deshpande, S.N.; Lerer, B.; Nimgaonkar, V.L.; Thelma, B.K. Genetic susceptibility to Tardive Dyskinesia in chronic schizophrenia subjects: V. Association of CYP1A2 1545 C>T polymorphism. Pharm. J. 2007, 7, 305-311. [CrossRef] [PubMed]

44. Kroon, L.A. Drug interactions with smoking. Am. J. Health Syst. Pharm. 2007, 64, 1917-1921. [CrossRef]

45. Du, J.; Zhang, A.; Wang, L.; Xuan, J.; Yu, L.; Che, R.; Li, X.; Gu, N.; Lin, Z.; Feng, G.; et al. Relationship between response to risperidone, plasma concentrations of risperidone and CYP3A4 polymorphisms in schizophrenia patients. J. Psychopharmacol. 2010, 24, 1115-1120. [CrossRef]

46. Xing, Q.; Gao, R.; Li, H.; Feng, G.; Xu, M.; Duan, S.; Meng, J.; Zhang, A.; Qin, S.; He, L. Polymorphisms of the ABCB1 gene are associated with the therapeutic response to risperidone in Chinese schizophrenia patients. Pharmacogenomics 2006, 7, 987-993. [CrossRef] [PubMed]

47. Bozina, N.; Kuzman, M.R.; Medved, V.; Jovanovic, N.; Sertic, J.; Hotujac, L. Associations between MDR1 gene polymorphisms and schizophrenia and therapeutic response to olanzapine in female schizophrenic patients. J. Psychiatr. Res. 2008, 42, 89-97. [CrossRef]

48. Lee, S.T.; Ryu, S.; Kim, S.R.; Kim, M.J.; Kim, S.; Kim, J.W.; Lee, S.Y.; Hong, K.S. Association study of 27 annotated genes for clozapine pharmacogenetics: Validation of preexisting studies and identification of a new candidate gene, ABCB1, for treatment response. J. Clin. Psychopharmacol. 2012, 32, 441-448. [CrossRef]

49. Schafer, M.; Rujescu, D.; Giegling, I.; Guntermann, A.; Erfurth, A.; Bondy, B.; Moller, H.J. Association of short-term response to haloperidol treatment with a polymorphism in the dopamine D receptor gene. Am. J. Psychiatry 2001, 158, 802-804. [CrossRef]

50. Suzuki, A.; Kondo, T.; Otani, K.; Mihara, K.; Yasui-Furukori, N.; Sano, A.; Koshiro, K.; Kaneko, S. Association of the TaqI A polymorphism of the dopamine D receptor gene with predisposition to neuroleptic malignant syndrome. Am. J. Psychiatry 2001, 158, 1714-1716. [CrossRef] 
51. Vijayan, N.N.; Bhaskaran, S.; Koshy, L.V.; Natarajan, C.; Srinivas, L.; Nair, C.M.; Allencherry, P.M.; Banerjee, M. Association of dopamine receptor polymorphisms with schizophrenia and antipsychotic response in a South Indian population. Behav. Brain Funct. 2007, 33, 4. [CrossRef]

52. Dahmen, N.; Muller, M.J.; Germeyer, S.; Rujescu, D.; Anghelescu, I.; Hiemke, C.; Wetzel, H. Genetic polymorphisms of the dopamine D2 and D3 receptor and neuroleptic drug effects in schizophrenic patients. Schizophr. Res. 2001, 49, 223-225. [CrossRef]

53. Lencz, T.; Robinson, D.G.; Xu, K.; Ekholm, J.; Sevy, S.; Gunduz-Bruce, H.; Woerner, M.G.; Kane, J.M.; Goldman, D.; Malhotra, A.K. DRD2 promoter region variation as a predictor of sustained response to antipsychotic medication in first-episode schizophrenia patients. Am. J. Psychiatry 2006, 163, 529-531. [CrossRef] [PubMed]

54. Cohen, B.M.; Ennulat, D.J.; Centorrino, F.; Matthysse, S.; Konieczna, H.; Chu, H.M.; Cherkerzian, S. Polymorphisms of the dopamine D4 receptor and response to antipsychotic drugs. Psychopharmacology 1999, 141, 6-10. [CrossRef] [PubMed]

55. Szekeres, G.; Keri, S.; Juhasz, A.; Rimanoczy, A.; Szendi, I.; Czimmer, C.; Janka, Z. Role of dopamine D3 receptor (DRD3) and dopamine transporter (DAT) polymorphism in cognitive dysfunctions and therapeutic response to atypical antipsychotics in patients with schizophrenia. Am. J. Med. Genet. B Neuropsychiatr. Genet. 2004, 124, 1-5. [CrossRef] [PubMed]

56. Reynolds, G.P.; Yao, Z.; Zhang, X.; Sun, J.; Zhang, Z. Pharmacogenetics of treatment in first-episode schizophrenia: D3 and 5-HT2C receptor polymorphisms separately associate with positive and negative symptom response. Eur. Neuropsychopharmacol. 2005, 15, 143-151. [CrossRef]

57. Anttila, S.; Illi, A.; Kampman, O.; Mattila, K.M.; Lehtimaki, T.; Leinonen, E. Interaction between NOTCH4 and catechol-Omethyltransferase genotypes in schizophrenia patients with poor response to typical neuroleptics. Pharmacogenetics 2004, 14, 303-307. [CrossRef] [PubMed]

58. Molero, P.; Ortuno, F.; Zalacain, M.; Patino-Garcia, A. Clinical involvement of catechol-O-methyltransferase polymorphisms in schizophrenia spectrum disorders: Influence on the severity of psychotic symptoms and on the response to neuroleptic treatment. Pharm. J. 2007, 7, 418-426. [CrossRef] [PubMed]

59. Weickert, T.W.; Goldberg, T.E.; Mishara, A.; Apud, J.A.; Kolachana, B.S.; Egan, M.F.; Weinberger, D.R. Catechol-Omethyltransferase val108/158met genotype predicts working memory response to antipsychotic medications. Biol. Psychiatry 2004, 56, 677-682. [CrossRef]

60. Woodward, N.D.; Jayathilake, K.; Meltzer, H.Y. COMT val108/158met genotype, cognitive function, and cognitive improvement with clozapine in schizophrenia. Schizophr. Res. 2007, 90, 86-96. [CrossRef] [PubMed]

61. Joober, R.; Benkelfat, C.; Brisebois, K.; Toulouse, A.; Turecki, G.; Lal, S.; Bloom, D.; Labelle, A.; Lalonde, P.; Fortin, D.; et al. T102C polymorphism in the 5HT2A gene and schizophrenia: Relation to phenotype and drug response variability. J. Psychiatry Neurosci. JPN 1999, 24, 141-146.

62. Arranz, M.J.; Munro, J.; Owen, M.J.; Spurlock, G.; Sham, P.C.; Zhao, J.; Kirov, G.; Collier, D.A.; Kerwin, R.W. Evidence for association between polymorphisms in the promoter and coding regions of the 5-HT2A receptor gene and response to clozapine. Mol. Psychiatry 1998, 3, 61-66. [CrossRef]

63. Hamdani, N.; Bonniere, M.; Ades, J.; Hamon, M.; Boni, C.; Gorwood, P. Negative symptoms of schizophrenia could explain discrepant data on the association between the 5-HT2A receptor gene and response to antipsychotics. Neurosci. Lett. 2005, 377, 69-74. [CrossRef] [PubMed]

64. Benmessaoud, D.; Hamdani, N.; Boni, C.; Ramoz, N.; Hamon, M.; Kacha, F.; Gorwood, P. Excess of transmission of the G allele of the $-1438 \mathrm{~A} / \mathrm{G}$ polymorphism of the $5-\mathrm{HT}_{2 \mathrm{~A}}$ receptor gene in patients with schizophrenia responsive to antipsychotics. $B M C$ Psychiatry 2008, 84, 1-7.

65. Müller, D.J.; De Luca, V.; Sicard, T.; King, N.; Hwang, R.; Volavka, J.; Czobor, P.; Sheitman, B.B.; Lindenmayer, J.P.; Citrome, L.; et al. Suggestive association between the C825T polymorphism of the G-protein beta3 subunit gene (GNB3) and clinical improvement with antipsychotics in schizophrenia. Eur. Neuropsychopharmacol. J. Eur. Coll. Neuropsychopharmacol. 2005, 15, 525-531. [CrossRef] [PubMed]

66. Kohlrausch, F.B.; Salatino-Oliveira, A.; Gama, C.S.; Lobato, M.I.; Belmonte-de-Abreu, P.; Hutz, M.H. G-protein gene 825C>T polymorphism is associated with response to clozapine in Brazilian schizophrenics. Pharmacogenomics 2008, 9, 1429-1436. [CrossRef] [PubMed]

67. Arranz, M.J.; Bolonna, A.A.; Munro, J.; Curtis, C.J.; Collier, D.A.; Kerwin, R.W. The serotonin transporter and clozapine response. Mol. Psychiatry 2000, 5, 124-125. [CrossRef]

68. Lee, H.Y.; Kim, D.J.; Lee, H.J.; Choi, J.E.; Kim, Y.K. No association of serotonin transporter polymorphism (5-HTTVNTR and 5-HTTLPR) with characteristics and treatment response to atypical antipsychotic agents in schizophrenic patients. Prog. Neuropsychopharmacol. Biol. Psychiatry 2009, 33, 276-280. [CrossRef]

69. Vázquez-Bourgon, J.; Arranz, M.J.; Mata, I.; Pelayo-Terán, J.M.; Pérez-Iglesias, R.; Medina-González, L.; Carrasco-Marín, E.; Vázquez-Barquero, J.L.; Crespo-Facorro, B. Serotonin transporter polymorphisms and early response to antipsychotic treatment in first episode of psychosis. Psychiatry Res. 2010, 175, 189-194. [CrossRef]

70. Strous, R.D.; Greenbaum, L.; Kanyas, K.; Merbl, Y.; Horowitz, A.; Karni, O.; Viglin, D.; Olender, T.; Deshpande, S.N.; Lancet, D.; et al. Association of the dopamine receptor interacting protein gene, NEF3, with early response to antipsychotic medication. Int. J. Neuropsychopharmacol. 2007, 10, 321-333. 
71. Krebs, M.O.; Guillin, O.; Bourdell, M.C.; Schwartz, J.C.; Olie, J.P.; Poirier, M.F.; Sokoloff, P. Brain derived neurotrophic factor (BDNF) gene variants association with age at onset and therapeutic response in schizophrenia. Mol. Psychiatry 2000, 5, 558-562. [CrossRef] [PubMed]

72. Zai, G.; Arnold, P.D.; Burroughs, E.; Richter, M.A.; Kennedy, J.L. Tumor necrosis factor-alpha gene is not associated with obsessive-compulsive disorder. Psychiatr. Genet. 2006, 16, 43-45. [CrossRef] [PubMed]

73. Kampman, O.; Anttila, S.; Illi, A.; Saarela, M.; Rontu, R.; Mattila, K.M.; Leinonen, E.; Lehtimaki, T. Neuregulin genotype and medication response in Finnish patients with schizophrenia. Neuroreport 2004, 15, 2517-2520. [CrossRef]

74. Joober, R.; Benkelfat, C.; Lal, S.; Bloom, D.; Labelle, A.; Lalonde, P.; Turecki, G.; Rozen, R.; Rouleau, G.A. Association between the methylenetetrahydrofolate reductase 677C $\rightarrow$ T missense mutation and schizophrenia. Mol. Psychiatry 2000, 5, 323-326. [CrossRef] [PubMed]

75. Hamdani, N.; Tabeze, J.P.; Ramoz, N.; Ades, J.; Hamon, M.; Sarfati, Y.; Boni, C.; Gorwood, P. The CNR1 gene as a pharmacogenetic factor for antipsychotics rather than a susceptibility gene for schizophrenia. Eur. Neuropsychopharmacol. 2008, 18, 34-40. [CrossRef] [PubMed]

76. Mancama, D.; Arranz, M.J.; Munro, J.; Osborne, S.; Makoff, A.; Collier, D.; Kerwin, R. Investigation of promoter variants of the histamine 1 and 2 receptors in schizophrenia and clozapine response. Neurosci. Lett. 2002, 333, 207-211. [CrossRef]

77. Zuo, L.; Luo, X.; Kranzler, H.R.; Lu, L.; Rosenheck, R.A.; Cramer, J.; van Kammen, D.P.; Erdos, J.; Charney, D.S.; Krystal, J.; et al. Association study of DTNBP1 with schizophrenia in a US sample. Psychiatr. Genet. 2009, 19, 292-304. [CrossRef]

78. Souza, R.P.; Ismail, P.; Meltzer, H.Y.; Kennedy, J.L. Variants in the oxytocin gene and risk for schizophrenia. Schizophr. Res. 2010, 121, 279-280. [CrossRef]

79. Souza, R.P.; de Luca, V.; Remington, G.; Lieberman, J.A.; Meltzer, H.Y.; Kennedy, J.L.; Wong, A.H. Glial cell line-derived neurotrophic factor receptor alpha 2 (GFRA2) gene is associated with tardive dyskinesia. Psychopharmacology 2010, 210, 347-354 [CrossRef]

80. Potkin, S.G.; Basile, V.S.; Jin, Y.; Masellis, M.; Badri, F.; Keator, D.; Wu, J.C.; Alva, G.; Carreon, D.T.; Bunney, W.E., Jr.; et al. D1 receptor alleles predict PET metabolic correlates of clinical response to clozapine. Mol. Psychiatry 2003, 8, 109-113. [CrossRef]

81. Hwang, R.; Shinkai, T.; De Luca, V.; Ni, X.; Potkin, S.G.; Lieberman, J.A.; Meltzer, H.Y.; Kennedy, J.L. Association study of four dopamine D1 receptor gene polymorphisms and clozapine treatment response. J. Psychopharmacol. 2007, 21, 718-727. [CrossRef] [PubMed]

82. Hwang, R.; Shinkai, T.; De Luca, V.; Müller, D.J.; Ni, X.; Macciardi, F.; Potkin, S.; Lieberman, J.A.; Meltzer, H.Y.; Kennedy, J.L. Association study of 12 polymorphisms spanning the dopamine $\mathrm{D}(2)$ receptor gene and clozapine treatment response in two treatment refractory/intolerant populations. Psychopharmacology 2005, 181, 179-187. [CrossRef] [PubMed]

83. Hwang, R.; Shinkai, T.; Deluca, V.; Macciardi, F.; Potkin, S.; Meltzer, H.Y.; Kennedy, J.L. Dopamine D2 receptor gene variants and quantitative measures of positive and negative symptom response following clozapine treatment. Eur. Neuropsychopharmacol. 2006, 16, 248-259. [CrossRef]

84. Shaikh, S.; Collier, D.A.; Sham, P.C.; Ball, D.; Aitchison, K.; Vallada, H.; Smith, I.; Gill, M.; Kerwin, R.W. Allelic association between a Ser-9-Gly polymorphism in the dopamine D3 receptor gene and schizophrenia. Hum. Genet. 1996, 97, 714-719. [CrossRef]

85. Scharfetter, J.; Chaudhry, H.R.; Hornik, K.; Fuchs, K.; Sieghart, W.; Kasper, S.; Aschauer, H.N. Dopamine D3 receptor gene polymorphism and response to clozapine in schizophrenic Pakastani patients. Eur. Neuropsychopharmacol. 1999, 10, 17-20. [CrossRef]

86. Zhao, A.L.; Zhao, J.P.; Zhang, Y.H.; Xue, Z.M.; Chen, J.D.; Chen, X.G. Dopamine D4 receptor gene exon III polymorphism and interindividual variation in response to clozapine. Int. J. Neurosci. 2005, 115, 1539-1547. [CrossRef]

87. Shaikh, S.; Collier, D.; Kerwin, R.W.; Pilowsky, L.S.; Gill, M.; Xu, W.M.; Thornton, A. Dopamine D4 receptor subtypes and response to clozapine. Lancet 1993, 341, 116. [CrossRef]

88. Hwang, R.; Zai, C.; Tiwari, A.; Müller, D.J.; Arranz, M.J.; Morris, A.G.; McKenna, P.J.; Munro, J.; Potkin, S.G.; Lieberman, J.A.; et al. Effect of dopamine D3 receptor gene polymorphisms and clozapine treatment response: Exploratory analysis of nine polymorphisms and meta-analysis of the Ser9Gly variant. Pharmacogenomics J. 2010, 10, 200-218. [CrossRef]

89. Rao, P.A.; Pickar, D.; Gejman, P.V.; Ram, A.; Gershon, E.S.; Gelernter, J. Allelic variation in the D4 dopamine receptor (DRD4) gene does not predict response to clozapine. Arch. Gen. Psychiatry 1994, 51, 912-917. [CrossRef]

90. Rietschel, M.; Naber, D.; Oberländer, H.; Holzbach, R.; Fimmers, R.; Eggermann, K.; Möller, H.J.; Propping, P.; Nöthen, M.M. Efficacy and side-effects of clozapine: Testing for association with allelic variation in the dopamine D4 receptor gene. Neuropsychopharmacol. Off. Publ. Am. Coll. Neuropsychopharmacol. 1996, 15, 491-496. [CrossRef]

91. Xu, M.; Xing, Q.; Li, S.; Zheng, Y.; Wu, S.; Gao, R.; Yu, L.; Guo, T.; Yang, Y.; Liu, J.; et al. Pharacogenetic effects of dopamine transporter gene polymorphisms on response to chlorpromazine and clozapine and on extrapyramidal syndrome in schizophrenia. Prog. Neuropsychopharmacol. Biol. Psychiatry 2010, 34, 1026-1032. [CrossRef]

92. Yu, Y.W.; Tsai, S.J.; Yang, K.H.; Lin, C.H.; Chen, M.C.; Hong, C.J. Evidence for an association between polymorphism in the serotonin-2A receptor variant (102T/C) and increment of N100 amplitude in schizophrenics treated with clozapine. Neuropsychobiology 2001, 43, 79-82. [CrossRef]

93. Masellis, M.; Basile, V.; Meltzer, H.Y.; Lieberman, J.A.; Sevy, S.; Macciardi, F.M.; Cola, P.; Howard, A.; Badri, F.; Nöthen, M.M.; et al. Serotonin subtype 2 receptor genes and clinical response to clozapine in schizophrenia patients. Neuropsychopharmacol. Off. Publ. Am. Coll. Neuropsychopharmacol. 1998, 19, 123-132. [CrossRef] 
94. Arranz, M.; Collier, D.; Sodhi, M.; Ball, D.; Roberts, G.; Price, J.; Sham, P.; Kerwin, R. Association between clozapine response and allelic variation in 5-HT2A receptor gene. Lancet 1995, 346, 281-282. [CrossRef]

95. Arranz, M.J.; Collier, D.A.; Munro, J.; Sham, P.; Kirov, G.; Sodhi, M.; Roberts, G.; Price, J.; Kerwin, R.W. Analysis of a structural polymorphism in the 5-HT2A receptor and clinical response to clozapine. Neurosci. Lett. 1996, 217, 177-178. [CrossRef]

96. Sodhi, M.S.; Arranz, M.J.; Curtis, D.; Ball, D.M.; Sham, P.; Roberts, G.W.; Price, J.; Collier, D.A.; Kerwin, R.W. Association between clozapine response and allelic variation in the 5-HT2C receptor gene. Neuroreport 1995, 7, 169-172. [CrossRef]

97. Arranz, M.J.; Munro, J.; Birkett, J.; Bolonna, A.; Mancama, D.; Sodhi, M.; Lesch, K.P.; Meyer, J.F.; Sham, P.; Collier, D.A.; et al. Pharmacogenetic prediction of clozapine response. Lancet 2000, 355, 1615-1616. [CrossRef]

98. Kohlrausch, F.B.; Salatino-Oliveira, A.; Gama, C.S.; Lobato, M.I.; Belmonte-de-Abreu, P.; Hutz, M.H. Influence of serotonin transporter gene polymorphisms on clozapine response in Brazilian schizophrenics. J. Psychiatr. Res. 2010, 44, 1158-1162. [CrossRef] [PubMed]

99. Nothen, M.M.; Rietschel, M.; Erdmann, J.; Oberlander, H.; Moller, H.J.; Nober, D.; Propping, P. Genetic variation of the 5-HT2A receptor and response to clozapine. Lancet 1995, 346, 908-909. [CrossRef]

100. Rietschel, M.; Naber, D.; Fimmers, R.; Moller, H.J.; Propping, P.; Nothen, M.M. Efficacy and side-effects of clozapine not associated with variation in the 5-HT2C receptor. Neuroreport 1997, 8, 1999-2003. [CrossRef] [PubMed]

101. Malhotra, A.K.; Goldman, D.; Ozaki, N.; Breier, A.; Buchanan, R.; Pickar, D. Lack of association between polymorphisms in the 5-HT2A receptor gene and the antipsychotic response to clozapine. Am. J. Psychiatry 1996, 153, 1092-1094.

102. Malhotra, A.K.; Goldman, D.; Ozaki, N.; Rooney, W.; Clifton, A.; Buchanan, R.W.; Breier, A.; Pickar, D. Clozapine response and the 5HT2C Cys23Ser polymorphism. Neuroreport 1996, 7, 2100-2102. [CrossRef]

103. Masellis, M.; Basile, V.S.; Meltzer, H.Y.; Lieberman, J.A.; Sevy, S.; Goldman, D.A.; Hamblin, M.W.; Macciardi, F.M.; Kennedy, J.L. Lack of association between the T->C 267 serotonin 5-HT6 receptor gene (HTR6) polymorphism and prediction of response to clozapine in schizophrenia. Schizophr. Res. 2001, 47, 49-58. [CrossRef]

104. Masellis, M.; Paterson, A.D.; Badri, F.; Lieberman, J.A.; Meltzer, H.Y.; Cavazzoni, P.; Kennedy, J.L. Genetic variation of 5-HT2A receptor and response to clozapine. Lancet 1995, 346, 1108. [CrossRef]

105. Birkett, J.T.; Arranz, M.J.; Munro, J.; Osbourn, S.; Kerwin, R.W.; Collier, D.A. Association analysis of the 5-HT5A gene in depression, psychosis and antipsychotic response. Neuroreport 2000, 11, 2017-2020. [CrossRef]

106. Gutiérrez, B.; Arranz, M.J.; Huezo-Diaz, P.; Dempster, D.; Matthiasson, P.; Travis, M.; Munro, J.; Osborne, S.; Kerwin, R.W. Novel mutations in 5-HT3A and 5-HT3B receptor genes not associated with clozapine response. Schizophr. Res. 2002, 58, 93-97. [CrossRef]

107. Kaiser, R.; Tremblay, P.B.; Schmider, J.; Henneken, M.; Dettling, M.; Müller-Oerlinghausen, B.; Uebelhack, R.; Roots, I.; Brockmöller, J. Serotonin transporter polymorphisms: No association with response to antipsychotic treatment, but associations with the schizoparanoid and residual subtypes of schizophrenia. Mol. Psychiatry 2001, 6, 179-185. [CrossRef]

108. Bolonna, A.A.; Arranz, M.J.; Munro, J.; Osborne, S.; Petouni, M.; Martinez, M.; Kerwin, R.W. No influence of adrenergic receptor polymorphisms on schizophrenia and antipsychotic response. Neurosci. Lett. 2000, 280, 65-68. [CrossRef]

109. Bolonna, A.A.; Kerwin, R.W.; Munro, J.; Arranz, M.J.; Makoff, A.J. Polymorphisms in the genes for mGluR types 7 and 8: Association studies with schizophrenia. Schizophr. Res. 2001, 47, 99-103. [CrossRef]

110. Tsai, S.J.; Wang, Y.C.; Yu Younger, W.Y.; Lin, C.H.; Yang, K.H.; Hong, C.J. Association analysis of polymorphism in the promoter region of the alpha2a-adrenoceptor gene with schizophrenia and clozapine response. Schizophr. Res. 2001, 49, 53-58. [CrossRef]

111. Lane, H.Y.; Lee, C.C.; Chang, Y.C.; Lu, C.T.; Huang, C.H.; Chang, W.H. Effects of dopamine $\mathrm{D}_{2}$ receptor Ser311Cys polymorphism and clinical factors on risperidone efficacy for positive and negative symptoms and social function. Int. J. Neuropsychopharmacol. 2004, 7, 461-470. [CrossRef]

112. Itokawa, M.; Arinami, T.; Toru, M. Advanced research on dopamine signaling to develop drugs for the treatment of mental disorders: Ser311Cys polymorphisms of the dopamine D2-receptor gene and schizophrenia. J. Pharmacol. Sci. 2010, 114, 1-5. [CrossRef]

113. Ikeda, M.; Yamanouchi, Y.; Kinoshita, Y.; Kitajima, T.; Yoshimura, R.; Hashimoto, S.; O’Donovan, M.C.; Nakamura, J.; Ozaki, N.; Iwata, N. Variants of dopamine and serotonin candidate genes as predictors of response to risperidone treatment in first-episode schizophrenia. Pharmacogenomics 2008, 9, 1437-1443. [CrossRef] [PubMed]

114. Xing, Q.; Qian, X.; Li, H.; Wong, S.; Wu, S.; Feng, G.; Duan, S.; Xu, M.; Gao, R.; Qin, W.; et al. The relationship between the therapeutic response to risperidone and the dopamine D2 receptor polymorphism in Chinese schizophrenia patients. The Int. J. Neuropsychopharmacol. 2007, 10, 631-637. [CrossRef]

115. Gupta, M.; Bhatnagar, P.; Grover, S.; Kaur, H.; Baghel, R.; Bhasin, Y.; Chauhan, C.; Verma, B.; Manduva, V.; Mukherjee, O. Association studies of catechol-O-methyltransferase (COMT) gene with schizophrenia and response to antipsychotic treatment. Pharmacogenomics 2009, 10, 385-397. [CrossRef]

116. Fijal, B.A.; Stauffer, V.L.; Kinon, B.J.; Conley, R.R.; Hoffmann, V.P.; Witte, M.M.; Zhao, F.; Houston, J.P. Analysis of gene variants previously associated with iloperidone response in patients with schizophrenia who are treated with risperidone. J. Clin. Psychiatry 2012, 73, 367-371. [CrossRef]

117. Lane, H.Y.; Chang, Y.C.; Chiu, C.C.; Chen, M.L.; Hsieh, M.H.; Chang, W.H. Association of risperidone treatment response with a polymorphism in the 5-HT(2A) receptor gene. Am. J. Psychiatry 2002, 159, 1593-1595. [CrossRef] 
118. Kim, B.; Choi, E.Y.; Kim, C.Y.; Song, K.; Joo, Y.H. Could HTR2A T102C and DRD3 Ser9Gly predict clinical improvement in patients with acutely exacerbated schizophrenia? Results from treatment responses to risperidone in a naturalistic setting. Hum. Psychopharmacol. 2008, 23, 61-67. [CrossRef]

119. Yamanouchi, Y.; Iwata, N.; Suzuki, T.; Kitajima, T.; Ikeda, M.; Ozaki, N. Effect of DRD2, 5-HT2A, and COMT genes on antipsychotic response to risperidone. Pharm. J. 2003, 3, 356-361. [CrossRef] [PubMed]

120. Xu, M.Q.; St Clair, D.; Feng, G.Y.; Lin, Z.G.; He, G.; Li, X.; He, L. BDNF gene is a genetic risk factor for schizophrenia and is related to the chlorpromazine-induced extrapyramidal syndrome in the Chinese population. Pharmacogenet. Genom. 2008, 18, 449-457. [CrossRef] [PubMed]

121. Fijal, B.A.; Kinon, B.J.; Kapur, S.; Stauffer, V.L.; Conley, R.R.; Jamal, H.H.; Kane, J.M.; Witte, M.M.; Houston, J.P. Candidate-gene association analysis of response to risperidone in African-American and white patients with schizophrenia. Pharm. J. 2009, 9, 311-318. [CrossRef] [PubMed]

122. Zalsman, G.; Frisch, A.; Lev-Ran, S.; Martin, A.; Michaelovsky, E.; Bensason, D.; Gothelf, D.; Nahshoni, E.; Tyano, S.; Weizman, A. DRD4 exon III polymorphism and response to risperidone in Israeli adolescents with schizophrenia: A pilot pharmacogenetic study. Eur. Neuropsychopharmacol. J. Eur. Coll. Neuropsychopharmacol. 2003, 13, 183-185. [CrossRef]

123. Lane, H.Y.; Hsu, S.K.; Liu, Y.C.; Chang, Y.C.; Huang, C.H.; Chang, W.H. Dopamine D3 receptor Ser9Gly polymorphism and risperidone response. J. Clin. Psychopharmacol. 2005, 25, 6-11. [CrossRef] [PubMed]

124. Liu, B.C.; Zhang, J.; Wang, L.; Li, X.W.; Wang, Y.; Wei, Z.Y.; Ji, J.; Yang, F.P.; Wan, C.L.; Xu, Y.F.; et al. HTR2C promoter polymorphisms are associated with risperidone efficacy in Chinese female patients. Pharmacogenomics 2010, 11, 685-692. [CrossRef]

125. Gu, B.; Wang, L.; Zhang, A.P.; Ma, G.; Zhao, X.Z.; Li, H.F.; Feng, G.Y.; He, L.; Xing, Q.H. Association between a polymorphism of the HTR3A gene and therapeutic response to risperidone treatment in drug-naive Chinese schizophrenia patients. Pharm. Genom. 2008, 18, 721-727. [CrossRef] [PubMed]

126. Lane, H.Y.; Lin, C.C.; Huang, C.H.; Chang, Y.C.; Hsu, S.K.; Chang, W.H. Risperidone response and 5-HT6 receptor gene variance: Genetic association analysis with adjustment for nongenetic confounders. Schizophr. Res. 2004, 67, 63-70. [CrossRef]

127. Wang, L.; Yu, L.; He, G.; Zhang, J.; Zhang, A.P.; Du, J.; Tang, R.Q.; Zhao, X.Z.; Ma, J.; Xuan, J.K.; et al. Response of risperidone treatment may be associated with polymorphisms of HTT gene in Chinese schizophrenia patients. Neurosci. Lett. 2007, 414, 1-4. [CrossRef]

128. Lane, H.Y.; Liu, Y.C.; Huang, C.L.; Chang, Y.C.; Wu, P.L.; Huang, C.H.; Tsai, G.E. RGS4 polymorphisms predict clinical manifestations and responses to risperidone treatment in patients with schizophrenia. J. Clin. Psychopharmacol. 2008, 28, 64-68. [CrossRef]

129. Wei, Z.; Wang, L.; Xuan, J.; Che, R.; Du, J.; Qin, S.; Xing, Y.; Gu, B.; Yang, L.; Li, H.; et al. Association analysis of serotonin receptor 7 gene (HTR7) and risperidone response in Chinese schizophrenia patients. Prog. Neuropsychopharmacol. Biol. Psychiatry 2009, 33, 547-551. [CrossRef]

130. Staddon, S.; Arranz, M.J.; Mancama, D.; Mata, I.; Kerwin, R.W. Clinical applications of pharmacogenetics in psychiatry. Psychopharmacology 2002, 162, 18-23. [CrossRef]

131. Adams, D.H.; Close, S.; Farmen, M.; Downing, A.M.; Breier, A.; Houston, J.P. Dopamine receptor D3 genotype association with greater acute positive symptom remission with olanzapine therapy in predominately caucasian patients with chronic schizophrenia or schizoaffective disorder. Hum. Psychopharmacol. 2008, 23, 267-274. [CrossRef] [PubMed]

132. Thomas, P.; Srivastava, V.; Singh, A.; Mathur, P.; Nimgaonkar, V.L.; Lerer, B.; Thelma, B.K.; Deshpande, S.N. Correlates of response to Olanzapine in a North Indian Schizophrenia sample. Psychiatry Res. 2008, 161, 275-283. [CrossRef]

133. Bertolino, A.; Caforio, G.; Blasi, G.; De Candia, M.; Latorre, V.; Petruzzella, V.; Altamura, M.; Nappi, G.; Papa, S.; Callicott, J.H.; et al. Interaction of COMT (Val(108/158)Met) genotype and olanzapine treatment on prefrontal cortical function in patients with schizophrenia. Am. J. Psychiatry 2004, 161, 1798-1805. [CrossRef]

134. Bozina, N.; Medved, V.; Kuzman, M.R.; Sain, I.; Sertic, J. Association study of olanzapine-induced weight gain and therapeutic response with SERT gene polymorphisms in female schizophrenic patients. J. Psychopharmacol. 2007, 21, 728-734. [CrossRef]

135. Houston, J.P.; Adams, D.H.; Kirkwood, S.C.; Farmen, M.; Downing, A.M.; Breier, A. Neuroreceptor gene polymorphisms and olanzapine depressive symptom response in schizophrenia. J. Clin. Psychopharmacol. 2007, 27, 520-523. [CrossRef]

136. Bishop, J.R.; Ellingrod, V.L.; Moline, J.; Miller, D. Association between the polymorphic GRM3 gene and negative symptom improvement during olanzapine treatment. Schizophr. Res. 2005, 77, 253-260. [CrossRef]

137. Porcelli, S.; Lee, S.J.; Han, C.; Patkar, A.A.; Serretti, A.; Pae, C.U. CACNA1C gene and schizophrenia: A case-control and pharmacogenetic study. Psychiatr. Genet. 2015, 25, 163-167. [CrossRef] [PubMed]

138. Nyegaard, M.; Demontis, D.; Foldager, L.; Hedemand, A.; Flint, T.J.; Sørensen, K.M.; Andersen, P.S.; Nordentoft, M.; Werge, T.; Pedersen, C.B.; et al. CACNA1C (rs1006737) is associated with schizophrenia. Mol. Psychiatry 2010, 15, 119-121. [CrossRef]

139. Natesan, S.; Kapur, S. Antipsychotic therapy over half a century: A tale of discovery from chlorpromazine to aripiprazole. Natl. Med. J. India 2012, 25, 193-195.

140. Kwon, J.S.; Kim, E.; Kang, D.H.; Choi, J.S.; Yu, K.S.; Jang, I.J.; Shin, S.G. Taq1A polymorphism in the dopamine D2 receptor gene as a predictor of clinical response to aripiprazole. Eur. Neuropsychopharmacol. 2008, 18, 897-907. [CrossRef]

141. Shen, Y.C.; Chen, S.F.; Chen, C.H.; Lin, C.C.; Chen, S.J.; Chen, Y.J.; Luu, S.U. Effects of DRD2/ANKK1 gene variations and clinical factors on aripiprazole efficacy in schizophrenic patients. J. Psychiatr. Res. 2009, 43, 600-606. [CrossRef] [PubMed] 
142. Liou, Y.J.; Lai, I.C.; Liao, D.L.; Chen, J.Y.; Lin, C.C.; Lin, C.Y.; Chen, C.M.; Bai, Y.M.; Chen, T.T.; Wang, Y.C. The human dopamine receptor D2 (DRD2) gene is associated with tardive dyskinesia in patients with schizophrenia. Schizophr. Res. 2006, 86, 323-325. [CrossRef] [PubMed]

143. Al Hadithy, A.F.; Wilffert, B.; Stewart, R.E.; Looman, N.M.; Bruggeman, R.; Brouwers, J.R.; Matroos, G.E.; van Os, J.; Hoek, H.W.; van Harten, P.N. Pharmacogenetics of parkinsonism, rigidity, rest tremor, and bradykinesia in African-Caribbean inpatients: Differences in association with dopamine and serotonin receptors. Am. J. Med. Genet. B. Neuropsychiatr. Genet. 2008, 147B, 890-897. [CrossRef] [PubMed]

144. Mo, G.H.; Lai, I.C.; Wang, Y.C.; Chen, J.Y.; Lin, C.Y.; Chen, T.T.; Chen, M.L.; Liou, Y.J.; Liao, D.L.; Bai, Y.M.; et al. Support for an association of the C939T polymorphism in the human DRD2 gene with tardive dyskinesia in schizophrenia. Schizophr. Res. 2007, 97, 302-304. [CrossRef]

145. Chen, C.H.; Wei, F.C.; Koong, F.J.; Hsiao, K.J. Association of TaqI A polymorphism of dopamine D2 receptor gene and tardive dyskinesia in schizophrenia. Biol. Psychiatry 1997, 41, 827-829. [CrossRef]

146. Gassó, P.; Mas, S.; Crescenti, A.; Alvarez, S.; Parramon, G.; Garcia-Rizo, C.; Parellada, E.; Bernardo, M.; Lafuente, A. Lack of association between antipsychotic-induced extrapyramidal symptoms and polymorphisms in dopamine metabolism and transport genes. Psychiatry Res. 2010, 175, 173-175. [CrossRef]

147. Srivastava, V.; Varma, P.G.; Prasad, S.; Semwal, P.; Nimgaonkar, V.L.; Lerer, B.; Deshpande, S.N.; Bk, T. Genetic susceptibility to tardive dyskinesia among schizophrenia subjects: IV. Role of dopaminergic pathway gene polymorphisms. Pharmacogenet. Genom. 2006, 16, 111-117. [CrossRef]

148. Lafuente, A.; Bernardo, M.; Mas, S.; Crescenti, A.; Aparici, M.; Gasso, P.; Deulofeu, R.; Mane, A.; Catalan, R.; Carne, X. Polymorphism of dopamine D2 receptor (TaqIA, TaqIB, and-141C Ins/Del) and dopamine degradation enzyme (COMT G158A, A-278G) genes and extrapyramidal symptoms in patients with schizophrenia and bipolar disorders. Psychiatry Res. 2008, 161, 131-141. [CrossRef]

149. Mihara, K.; Suzuki, A.; Kondo, T.; Nagashima, U.; Ono, S.; Otani, K.; Kaneko, S. No relationship between Taq1 a polymorphism of dopamine D receptor gene and extrapyramidal adverse effects of selective dopamine D antagonists, bromperidol, and nemonapride in schizophrenia: A preliminary study. Am. J. Med. Genet. 2000, 96, 422-424. [CrossRef]

150. Lattuada, E.; Cavallaro, R.; Serretti, A.; Lorenzi, C.; Smeraldi, E. Tardive dyskinesia and DRD2, DRD3, DRD4, 5-HT2A variants in schizophrenia: An association study with repeated assessment. Int. J. Neuropsychopharmacol. 2004, 7, 489-493. [CrossRef]

151. Mihara, K.; Kondo, T.; Suzuki, A.; Yasui, N.; Ono, S.; Otani, K.; Kaneko, S. No relationship between--141C Ins/Del polymorphism in the promoter region of dopamine D2 receptor and extrapyramidal adverse effects of selective dopamine D2 antagonists in schizophrenic patients: A preliminary study. Psychiatry Res. 2001, 101, 33-38. [CrossRef]

152. Chong, S.A.; Tan, E.C.; Tan, C.H. Smoking and tardive dyskinesia: Lack of involvement of the CYP1A2 gene. J. Psychiatry Neurosci. 2003, 28, 185-189. [PubMed]

153. Hori, H.; Ohmori, O.; Shinkai, T.; Kojima, H.; Nakamura, J. Association between three functional polymorphisms of dopamine D2 receptor gene and tardive dyskinesia in schizophrenia. Am. J. Med. Genet. 2001, 105, 774-778. [CrossRef] [PubMed]

154. Kaiser, R.; Tremblay, P.B.; Klufmoller, F.; Roots, I.; Brockmoller, J. Relationship between adverse effects of antipsychotic treatment and dopamine D receptor polymorphisms in patients with schizophrenia. Mol. Psychiatry 2002, 7, 695-705. [CrossRef]

155. Dolzan, V.; Plesnicar, B.K.; Serretti, A.; Mandelli, L.; Zalar, B.; Koprivsek, J.; Breskvar, K. Polymorphisms in dopamine receptor DRD1 and DRD2 genes and psychopathological and extrapyramidal symptoms in patients on long-term antipsychotic treatment. Am. J. Med. Genet. B Neuropsychiatr. Genet. 2007, 144, 809-815. [CrossRef] [PubMed]

156. Gasso, P.; Mas, S.; Bernardo, M.; Alvarez, S.; Parellada, E.; Lafuente, A. A common variant in DRD3 gene is associated with risperidone-induced extrapyramidal symptoms. Pharm. J. 2009, 9, 404-410. [CrossRef] [PubMed]

157. Steen, V.M.; Lovlie, R.; MacEwan, T.; McCreadie, R.G. Dopamine D3-receptor gene variant and susceptibility to tardive dyskinesia in schizophrenic patients. Mol. Psychiatry 1997, 2, 139-145. [CrossRef]

158. Segman, R.; Neeman, T.; Heresco-Levy, U.; Finkel, B.; Karagichev, L.; Schlafman, M.; Dorevitch, A.; Yakir, A.; Lerner, A.; Shelevoy, A.; et al. Genotypic association between the dopamine D3 receptor and tardive dyskinesia in chronic schizophrenia. Mol. Psychiatry 1999, 4, 247-253. [CrossRef] [PubMed]

159. Lerer, B.; Segman, R.H.; Fangerau, H.; Daly, A.K.; Basile, V.S.; Cavallaro, R.; Aschauer, H.N.; McCreadie, R.G.; Ohlraun, S.; Ferrier, N.; et al. Pharmacogenetics of tardive dyskinesia: Combined analysis of 780 patients supports association with dopamine D3 receptor gene Ser9Gly polymorphism. Neuropsychopharmacol. Off. Publ. Am. Coll. Neuropsychopharmacol. 2002, 27, 105-119. [CrossRef]

160. Liao, D.L.; Yeh, Y.C.; Chen, H.M.; Chen, H.; Hong, C.J.; Tsai, S.J. Association between the Ser9Gly polymorphism of the dopamine D3 receptor gene and tardive dyskinesia in Chinese schizophrenic patients. Neuropsychobiology 2001, 44, 95-98. [CrossRef]

161. Woo, S.I.; Kim, J.W.; Rha, E.; Han, S.H.; Hahn, K.H.; Park, C.S.; Sohn, J.W. Association of the Ser9Gly polymorphism in the dopamine D3 receptor gene with tardive dyskinesia in Korean schizophrenics. Psychiatry Clin. Neurosci. 2002, 56, 469-474. [CrossRef] [PubMed]

162. Eichhammer, P.; Albus, M.; Borrmann-Hassenbach, M.; Schoeler, A.; Putzhammer, A.; Frick, U.; Klein, H.E.; Rohrmeier, T. Association of dopamine D3-receptor gene variants with neuroleptic induced akathisia in schizophrenic patients: A generalization of Steen's study on DRD3 and tardive dyskinesia. Am. J. Med. Genet. 2000, 96, 187-191. [CrossRef] 
163. Rizos, E.N.; Nikolaos, S.; Katsantoni, E.; Lazou, V.; Sakellaropoulos, K.; Kastania, A.; Kossida, S.; Chatzigeorgiou, K.-S.; Arsenis, G.; Zerva, L.; et al. Association of the dopamine D3 receptor Ser9Gly and of the serotonin 2C receptor gene polymorphisms with tardive dyskinesia in Greeks with chronic schizophrenic disorder. Psychiatr. Genet. 2009, 19, 106-107. [CrossRef] [PubMed]

164. Mihara, K.; Kondo, T.; Higuchi, H.; Takahashi, H.; Yoshida, K.; Shimizu, T.; Kaneko, S. Tardive dystonia and genetic polymorphisms of cytochrome P4502D6 and dopamine D2 and D3 receptors: A preliminary finding. Am. J. Med. Genet. 2002, 114, 693-695. [CrossRef]

165. Liou, Y.J.; Liao, D.L.; Chen, J.Y.; Wang, Y.C.; Lin, C.C.; Bai, Y.M.; Yu, S.C.; Lin, M.W.; Lai, I.C. Association analysis of the dopamine D3 receptor gene ser9gly and brain-derived neurotrophic factor gene val66met polymorphisms with antipsychotic-induced persistent tardive dyskinesia and clinical expression in Chinese schizophrenic patients. Neuromolecular Med. 2004, 5, $243-251$. [CrossRef]

166. Rietschel, M.; Krauss, H.; Müller, D.J.; Schulze, T.G.; Knapp, M.; Marwinski, K.; Maroldt, A.O.; Paus, S.; Grünhage, F.; Propping, P.; et al. Dopamine D3 receptor variant and tardive dyskinesia. Eur. Arch. Psychiatry Clin. Neurosci. 2002, 250, 31-35. [CrossRef]

167. Garcia-Barcelo, M.M.; Lam, L.C.; Ungvari, G.S.; Lam, V.K.; Tang, W.K. Dopamine D3 receptor gene and tardive dyskinesia in Chinese schizophrenic patients. J. Neural. Transm. 2001, 108, 671-677. [CrossRef]

168. Zai, C.C.; Tiwari, A.K.; De Luca, V.; Müller, D.J.; Bulgin, N.; Hwang, R.; Zai, G.C.; King, N.; Voineskos, A.N.; Meltzer, H.Y.; et al. Genetic study of BDNF, DRD3, and their interaction in tardive dyskinesia. Eur. Neuropsychopharmacol. J. Eur. Coll. Neuropsychopharmacol. 2009, 19, 317-328. [CrossRef]

169. Chong, S.A.; Tan, E.C.; Tan, C.H.; Mythily Chan, Y.H. Polymorphisms of dopamine receptors and tardive dyskinesia among Chinese patients with schizophrenia. Am. J. Med. Genet. B Neuropsychiatr. Genet. 2003, 116, 51-54. [CrossRef]

170. Wilffert, B.; Al Hadithy, A.F.; Sing, V.J.; Matroos, G.; Hoek, H.W.; van Os, J.; Bruggeman, R.; Brouwers, J.R.; van Harten, P.N. The role of dopamine D3, 5-HT2A and 5-HT2C receptor variants as pharmacogenetic determinants in tardive dyskinesia in AfricanCaribbean patients under chronic antipsychotic treatment: Curacao extrapyramidal syndromes study IX. J. Psychopharmacol. 2009, 23, 652-659. [CrossRef] [PubMed]

171. Srivastava, V.; Deshpande, S.N.; Nimgaonkar, V.L.; Lerer, B.; Thelma, B. Genetic correlates of olanzapine-induced weight gain in schizophrenia subjects from north India: Role of metabolic pathway genes. Pharmacogenomics 2008, 9, 1055-1068. [CrossRef] [PubMed]

172. Herken, H.; Erdal, M.E.; Boke, O.; Savas, H.A. Tardive dyskinesia is not associated with the polymorphisms of 5-HT2A receptor gene, serotonin transporter gene and catechol-o-methyltransferase gene. Eur. Psychiatry 2003, 18, 77-81. [CrossRef]

173. Lai, I.C.; Wang, Y.C.; Lin, C.C.; Bai, Y.M.; Liao, D.L.; Yu, S.C.; Lin, C.Y.; Chen, J.Y.; Liou, Y.J. Negative association between catechol-O-methyltransferase (COMT) gene Val158Met polymorphism and persistent tardive dyskinesia in schizophrenia. J. Neural Transm. 2005, 112, 1107-1113. [CrossRef]

174. Matsumoto, C.; Shinkai, T.; Hori, H.; Ohmori, O.; Nakamura, J. Polymorphisms of dopamine degradation enzyme (COMT and MAO) genes and tardive dyskinesia in patients with schizophrenia. Psychiatry Res. 2004, 127, 1-7. [CrossRef] [PubMed]

175. Lafuente, A.; Bernardo, M.; Mas, S.; Crescenti, A.; Aparici, M.; Gasso, P.; Catalan, R.; Mateos, J.J.; Lomeña, F.; Parellada, E. Dopamine transporter (DAT) genotype (VNTR) and phenotype in extrapyramidal symptoms induced by antipsychotics. Schizophr. Res. 2007, 90, 115-122. [CrossRef]

176. Greenbaum, L.; Strous, R.D.; Kanyas, K.; Merbl, Y.; Horowitz, A.; Karni, O.; Katz, E.; Kotler, M.; Olender, T.; Deshpande, S.N.; et al. Association of the RGS2 gene with extrapyramidal symptoms induced by treatment with antipsychotic medication. Pharm. Genom. 2007, 17, 519-528. [CrossRef] [PubMed]

177. Greenbaum, L.; Smith, R.C.; Rigbi, A.; Strous, R.; Teltsh, O.; Kanyas, K.; Korner, M.; Lancet, D.; Ben-Asher, E.; Lerer, B. Further evidence for association of the RGS2 gene with antipsychotic-induced parkinsonism: Protective role of a functional polymorphism in the 3'-untranslated region. Pharm. J. 2009, 9, 103-110. [CrossRef]

178. Higa, M.; Ohnuma, T.; Maeshima, H.; Hatano, T.; Hanzawa, R.; Shibata, N.; Sakai, Y.; Suzuki, T.; Arai, H. Association analysis between functional polymorphism of the rs4606 SNP in the RGS2 gene and antipsychotic-induced Parkinsonism in Japanese patients with schizophrenia: Results from the Juntendo University Schizophrenia Projects (JUSP). Neurosci. Lett. 2010, 469, 55-59. [CrossRef]

179. Tan, E.C.; Chong, S.A.; Mahendran, R.; Dong, F.; Tan, C.H. Susceptibility to neuroleptic-induced tardive dyskinesia and the T102C polymorphism in the serotonin type 2A receptor. Biol Psychiatry 2001, 50, 144-147. [CrossRef]

180. Segman, R.H.; Heresco-Levy, U.; Finkel, B.; Goltser, T.; Shalem, R.; Schlafman, M.; Dorevitch, A.; Yakir, A.; Greenberg, D.; Lerner, A.; et al. Association between the serotonin 2A receptor gene and tardive dyskinesia in chronic schizophrenia. Mol. Psychiatry 2001, 6, 225-229. [CrossRef]

181. Deshpande, S.N.; Varma, P.G.; Semwal, P.; Rao, A.R.; Bhatia, T.; Nimgaonkar, V.L.; Lerer, B.; Thelma, B.K.I.I. Serotonin receptor gene polymorphisms and their association with tardive dyskinesia among schizophrenia patients from North India. Psychiatr Genet. 2005, 15, 157-158. [CrossRef]

182. Basile, V.S.; Ozdemir, V.; Masellis, M.; Meltzer, H.Y.; Lieberman, J.A.; Potkin, S.G.; Macciardi, F.M.; Petronis, A.; Kennedy, J.L. Lack of association between serotonin-2A receptor gene (HTR2A) polymorphisms and tardive dyskinesia in schizophrenia. Mol. Psychiatry 2001, 6, 230-234. [CrossRef] 
183. Zhang, Z.J.; Zhang, X.B.; Sha, W.W.; Zhang, X.B.; Reynolds, G.P. Association of a polymorphism in the promoter region of the serotonin 5-HT2C receptor gene with tardive dyskinesia in patients with schizophrenia. Mol. Psychiatry 2002, 7, 670-671. [CrossRef]

184. Segman, R.H.; Heresco-Levy, U.; Finkel, B.; Inbar, R.; Neeman, T.; Schlafman, M.; Dorevitch, A.; Yakir, A.; Lerner, A.; Goltser, T.; et al. Association between the serotonin 2C receptor gene and tardive dyskinesia in chronic schizophrenia: Additive contribution of 5-HT2Cser and DRD3gly alleles to susceptibility. Psychopharmacology 2000, 152, 408-413. [CrossRef]

185. Segman, R.H.; Lerer, B. Age and the relationship of dopamine D3, serotonin $2 \mathrm{C}$ and serotonin $2 \mathrm{~A}$ receptor genes to abnormal involuntary movements in chronic schizophrenia. Mol. Psychiatry 2002, 7, 137-139. [CrossRef]

186. Ohmori, O.; Shinkai, T.; Hori, H.; Nakamura, J. Genetic association analysis of 5-HT receptor gene polymorphism (267C/T) with tardive dyskinesia. Psychiatry Res. 2002, 110, 97-102. [CrossRef]

187. Chong, S.A.; Tan, E.C.; Tan, C.H.; Mahendren, R.; Tay, A.H.; Chua, H.C. Tardive dyskinesia is not associated with the serotonin gene polymorphism (5-HTTLPR) in Chinese. Am. J. Med. Genet. 2000, 96, 712-715. [CrossRef]

188. Park, S.W.; Lee, J.G.; Kong, B.G.; Lee, S.J.; Lee, C.H.; Kim, J.I.; Kim, Y.H. Genetic association of BDNF val66met and GSK-3beta50T/C polymorphisms with tardive dyskinesia. Psychiatry Clin. Neurosci. 2009, 63, 433-439. [CrossRef]

189. Kastelic, M.; Koprivsek, J.; Plesnicar, B.K.; Serretti, A.; Mandelli, L.; Locatelli, I.; Grabnar, I.; Dolzan, V. MDR1 gene polymorphisms and response to acute risperidone treatment. Prog. Neuropsychopharmacol. Biol. Psychiatry 2010, 34, 387-392. [CrossRef]

190. Zhang, Z.; Zhang, X.; Hou, G.; Sha, W.; Reynolds, G.P. The increased activity of plasma manganese superoxide dismutase in tardive dyskinesia is unrelated to the Ala-9Val polymorphism. J. Psychiatr. Res. 2002, 36, 317-324. [CrossRef]

191. Pae, C.U.; Kim, T.S.; Patkar, A.A.; Kim, J.J.; Lee, C.U.; Lee, S.J.; Jun, T.Y.; Lee, C.; Paik, I.H. Manganese superoxide dismutase (MnSOD: Ala-9Val) gene polymorphism may not be associated with schizophrenia and tardive dyskinesia. Psychiatry Res. 2007, 153, 77-81. [CrossRef]

192. Liu, H.; Wang, C.; Chen, P.H.; Zhang, B.S.; Zheng, Y.L.; Zhang, C.X.; Meng, H.Q.; Wang, Y.; Chen, D.C.; Xiu, M.H.; et al. Association of the manganese superoxide dismutase gene Ala-9Val polymorphism with clinical phenotypes and tardive dyskinesia in schizophrenic patients. Prog. Neuro Psychopharmacol. Biol. Psychiatry 2010, 34, 692-696. [CrossRef] [PubMed]

193. Wang, Y.C.; Liou, Y.J.; Liao, D.L.; Bai, Y.M.; Lin, C.C.; Yu, S.C.; Chen, J.Y. Association analysis of a neural nitric oxide synthase gene polymorphism and antipsychotics-induced tardive dyskinesia in Chinese schizophrenic patients. J. Neural. Transm. 2004, 111, 623-629. [CrossRef]

194. Shinkai, T.; Ohmori, O.; Matsumoto, C.; Hori, H.; Kennedy, J.L.; Nakamura, J. Genetic association analysis of neuronal nitric oxide synthase gene polymorphism with tardive dyskinesia. Neuromolecular. Med. 2004, 5, 163-170. [CrossRef]

195. Liou, Y.J.; Wang, Y.C.; Lin, C.C.; Bai, Y.M.; Lai, I.C.; Liao, D.L.; Chen, J.Y. Association analysis of NAD(P) Hratioquinone oxidoreductase (NQO1) Pro187Ser genetic polymorphism and tardive dyskinesia in patients with schizophrenia in Taiwan. Int. J. Neuropsychopharmacol. 2005, 8, 483-486. [CrossRef]

196. Shinkai, T.; De Luca, V.; Hwang, R.; Matsumoto, C.; Hori, H.; Ohmori, O.; Remington, G.; Meltzer, H.Y.; Lieberman, J.A.; Potkin, S.G.; et al. Association study between a functional glutathione S-transferase (GSTP1) gene polymorphism (Ile105Val) and tardive dyskinesia. Neurosci. Lett. 2005, 388, 116-120. [CrossRef]

197. Shinkai, T.; Müller, D.J.; De Luca, V.; Shaikh, S.; Matsumoto, C.; Hwang, R.; King, N.; Trakalo, J.; Potapova, N.; Zai, G.; et al. Genetic association analysis of the glutathione peroxidase (GPX1) gene polymorphism (Pro197Leu) with tardive dyskinesia. Psychiatry Res. 2006, 141, 123-128. [CrossRef] [PubMed]

198. Liou, Y.J.; Lai, I.C.; Lin, M.W.; Bai, Y.M.; Lin, C.C.; Liao, D.L.; Chen, J.Y.; Lin, C.Y.; Wang, Y.C. Haplotype analysis of endothelial nitric oxide synthase (NOS3) genetic variants and tardive dyskinesia in patients with schizophrenia. Pharm. Genom. 2006, 16, 151-157. [CrossRef]

199. Pae, C.U.; Yu, H.S.; Kim, J.J.; Lee, C.U.; Lee, S.J.; Jun, T.Y.; Lee, C.; Paik, I.H. Quinone oxidoreductase (NQO1) gene polymorphism $(609 \mathrm{C} / \mathrm{T})$ may be associated with tardive dyskinesia, but not with the development of schizophrenia. Int. J. Neuropsychopharmacol. 2004, 7, 495-500. [CrossRef] [PubMed]

200. Xu, M.Q.; Xing, Q.H.; Zheng, Y.L.; Li, S.; Gao, J.J.; He, G.; Guo, T.W.; Feng, G.Y.; Xu, F.; He, L. Association of AKT1 gene polymorphisms with risk of schizophrenia and with response to antipsychotics in the Chinese population. J. Clin. Psychiatry 2007, 68, 1358-1367. [CrossRef]

201. Saiz, P.A.; Susce, M.T.; Clark, D.A.; Kerwin, R.W.; Molero, P.; Arranz, M.J.; de Leon, J. An investigation of the alpha1A-adrenergic receptor gene and antipsychotic-induced side-effects. Hum. Psychopharmacol. 2008, 23, 107-114. [CrossRef]

202. Young, R.M.; Lawford, B.R.; Barnes, M.; Burton, S.C.; Ritchie, T.; Ward, W.K.; Noble, E.P. Prolactin levels in antipsychotic treatment of patients with schizophrenia carrying the DRD2*A1 allele. Br. J. Psychiatry 2004, 1851, 47-151. [CrossRef] [PubMed]

203. Kirk, S.L.; Glazebrook, J.; Grayson, B.; Neill, J.C.; Reynolds, G.P. Olanzapine-induced weight gain in the rat: Role of 5-HT2C and histamine H1 receptors. Psychopharmacology 2009, 207, 119-125. [CrossRef]

204. Ellingrod, V.L.; Perry, P.J.; Ringold, J.C.; Lund, B.C.; Bever-Stille, K.; Fleming, F.; Holman, T.L.; Miller, D. Weight gain associated with the $-759 \mathrm{C} / \mathrm{T}$ polymorphism of the $5 \mathrm{HT} 2 \mathrm{C}$ receptor and olanzapine. Am. J. Med. Genet. B Neuropsychiatr. Genet. 2005, 134, 76-78. [CrossRef]

205. Godlewska, B.R.; Olajossy-Hilkesberger, L.; Ciwoniuk, M.; Olajossy, M.; Marmurowska-Michalowska, H.; Limon, J.; Landowski, J. Olanzapine-induced weight gain is associated with the $-759 \mathrm{C} / \mathrm{T}$ and $-697 \mathrm{G} / \mathrm{C}$ polymorphisms of the HTR2C gene. Pharmacogenom. J. 2009, 9, 234-241. [CrossRef] 
206. Reynolds, G.P.; Zhang, Z.J.; Zhang, X.B. Association of antipsychotic drug-induced weight gain with a 5-HT2C receptor gene polymorphism. Lancet 2002, 359, 2086-2087. [CrossRef]

207. Reynolds, G.P.; Zhang, Z.; Zhang, X. Polymorphism of the promoter region of the serotonin $5-\mathrm{HT}_{2 \mathrm{C}}$ receptor gene and clozapineinduced weight gain. Am. J. Psychiatry 2003, 160, 677-679. [CrossRef]

208. Miller, D.D.; Ellingrod, V.L.; Holman, T.L.; Buckley, P.F.; Arndt, S. Clozapine-induced weight gain associated with the 5HT2C receptor-759C/T polymorphism. Am. J. Med. Genet. B Neuropsychiatr. Genet. 2005, 133, 97-100. [CrossRef]

209. Templeman, L.A.; Reynolds, G.P.; Arranz, B.; San, L. Polymorphisms of the 5-HT2C receptor and leptin genes are associated with antipsychotic drug-induced weight gain in Caucasian subjects with a first-episode psychosis. Pharmacogenet. Genom. 2005, 15, 195-200. [CrossRef]

210. Ryu, S.; Cho, E.Y.; Park, T.; Oh, S.; Jang, W.S.; Kim, S.K.; Lee, D.; Hong, K.S. -759 C/T polymorphism of 5-HT2C receptor gene and early phase weight gain associated with antipsychotic drug treatment. Prog. Neuropsychopharmacol. Biol. Psychiatry 2007, 31, 673-677. [CrossRef]

211. Del Castillo, N.; Zimmerman, M.B.; Tyler, B.; Ellingrod, V.L.; Calarge, C. 759C/T Variants of the Serotonin (5-HT2C) Receptor Gene and Weight Gain in Children and Adolescents in Long-Term Risperidone Treatment. Clin. Pharmacol. Biopharm. 2013, 2, 110.

212. De Luca, V.; Mueller, D.J.; de Bartolomeis, A.; Kennedy, J.L. Association of the HTR2C gene and antipsychotic induced weight gain: A meta-analysis. Int. J. Neuropsychopharmacol. 2007, 10, 697-704. [CrossRef]

213. Tsai, S.J.; Hong, C.J.; Yu, Y.W.; Lin, C.H. $-759 \mathrm{C} / \mathrm{T}$ genetic variation of $5 \mathrm{HT}_{2 \mathrm{C}}$ receptor and clozapine-induced weight gain. Lancet 2002, 360, 1790. [CrossRef]

214. Theisen, F.M.; Hinney, A.; Bromel, T.; Heinzel-Gutenbrunner, M.; Martin, M.; Krieg, J.C.; Remschmidt, H.; Hebebrand, J. Lack of association between the $-759 \mathrm{C} / \mathrm{T}$ polymorphism of the $5-\mathrm{HT} 2 \mathrm{C}$ receptor gene and clozapine-induced weight gain among German schizophrenic individuals. Psychiatr. Genet. 2004, 14, 139-142. [CrossRef]

215. Park, Y.M.; Cho, J.H.; Kang, S.G.; Choi, J.E.; Lee, S.H.; Kim, L.; Lee, H.J. Lack of association between the -759C/T polymorphism of the 5-HT2C receptor gene and olanzapine-induced weight gain among Korean schizophrenic patients. J. Clin. Pharm. Ther. 2008, 33, 55-60. [CrossRef]

216. Yevtushenko, O.O.; Cooper, S.J.; O’Neill, R.; Doherty, J.K.; Woodside, J.V.; Reynolds, G.P. Influence of 5-HT2C receptor and leptin gene polymorphisms, smoking and drug treatment on metabolic disturbances in patients with schizophrenia. Br. J. Psychiatry 2008, 192, 424-428. [CrossRef]

217. Kuzman, M.R.; Medved, V.; Bozina, N.; Hotujac, L.; Sain, I.; Bilusic, H. The influence of 5-HT $2 \mathrm{C}$ and MDR1 genetic polymorphisms on antipsychotic-induced weight gain in female schizophrenic patients. Psychiatry Res. 2008, 160, 308-315. [CrossRef] [PubMed]

218. Popp, J.; Leucht, S.; Heres, S.; Steimer, W. DRD4 48 bp VNTR but not 5- $\mathrm{HT}_{2 \mathrm{C}}$ Cys23Ser receptor polymorphism is related to antipsychotic-induced weight gain. Pharmacogenom. J. 2009, 9, 71-77. [CrossRef] [PubMed]

219. Hong, C.J.; Lin, C.H.; Yu, Y.W.; Yang, K.H.; Tsai, S.J. Genetic variants of the serotonin system and weight change during clozapine treatment. Pharmacogenetics 2001, 11, 265-268. [CrossRef]

220. Lane, H.Y.; Liu, Y.C.; Huang, C.L.; Chang, Y.C.; Wu, P.L.; Lu, C.T.; Chang, W.H. Risperidone-related weight gain: Genetic and nongenetic predictors. J. Clin. Psychopharmacol. 2006, 26, 128-134. [CrossRef] [PubMed]

221. Al-Janabi, I.; Arranz, M.J.; Blakemore, A.I.; Saiz, P.A.; Susce, M.T.; Glaser, P.E.; Clark, D.; de Leon, J. Association study of serotonergic gene variants with antipsychotic-induced adverse reactions. Psychiatr. Genet. 2009, 19, 305-311. [CrossRef]

222. Zhang, Z.J.; Yao, Z.J.; Zhang, X.B.; Chen, J.F.; Sun, J.; Yao, H.; Hou, G.; Zhang, X.B. No association of antipsychotic agent-induced weight gain with a DA receptor gene polymorphism and therapeutic response. Acta Pharmacol. Sin. 2003, $24,235-240$.

223. Müller, D.J.; Zai, C.C.; Sicard, M.; Remington, E.; Souza, R.P.; Tiwari, A.K.; Hwang, R.; Likhodi, O.; Shaikh, S.; Freeman, N.; et al. Systematic analysis of dopamine receptor genes (DRD1-DRD5) in antipsychotic-induced weight gain. Pharm. J. 2012, 12, 156-164. [CrossRef]

224. Lencz, T.; Robinson, D.G.; Napolitano, B.; Sevy, S.; Kane, J.M.; Goldman, D.; Malhotra, A.K. DRD2 promoter region variation predicts antipsychotic-induced weight gain in first episode schizophrenia. Pharmacogenet. Genom. 2010, 20, 569-572. [CrossRef]

225. Chowdhury, N.I.; Tiwari, A.K.; Souza, R.P.; Zai, C.C.; Shaikh, S.A.; Chen, S.; Liu, F.; Lieberman, J.A.; Meltzer, H.Y.; Malhotra, A.K.; et al. Genetic association study between antipsychotic-induced weight gain and the melanocortin-4 receptor gene. Pharm. J. 2013, 13, 272-279. [CrossRef]

226. Czerwensky, F.; Leucht, S.; Steimer, W. MC4R rs489693: A clinical risk factor for second generation antipsychotic-related weight gain? Int. J. Neuropsychopharmacol. 2013, 16, 2103-2109. [CrossRef] [PubMed]

227. Park, Y.M.; Chung, Y.C.; Lee, S.H.; Lee, K.J.; Kim, H.; Byun, Y.C.; Lim, S.W.; Paik, J.W.; Lee, H.J. Weight gain associated with the alpha2a-adrenergic receptor -1,291 C/G polymorphism and olanzapine treatment. Am. J. Med Genet. Part B Neuropsychiatr. Genet. 2006, 141B, 394-397. [CrossRef]

228. Wang, Y.C.; Bai, Y.M.; Chen, J.Y.; Lin, C.C.; Lai, I.C.; Liou, Y.J. Polymorphism of the adrenergic receptor alpha 2a -1291C>G genetic variation and clozapine-induced weight gain. J. Neural Transm. 2005, 112, 1463-1468. [CrossRef] [PubMed]

229. Sickert, L.; Muller, D.J.; Tiwari, A.K.; Shaikh, S.; Zai, C.; De Souza, R.; De Luca, V.; Meltzer, H.Y.; Lieberman, J.A.; Kennedy, J.L. Association of the alpha $2 \mathrm{~A}$ adrenergic receptor-1291C/G polymorphism and antipsychotic-induced weight gain in EuropeanAmericans. Pharmacogenomics 2009, 10, 1169-1176. [CrossRef] [PubMed]

230. Liu, Y.R.; Loh, E.W.; Lan, T.H.; Chen, S.F.; Yu, Y.H.; Chang, Y.H.; Huang, C.J.; Hu, T.M.; Lin, K.M.; Yao, Y.T.; et al. ADRA1A gene is associated with BMI in chronic schizophrenia patients exposed to antipsychotics. Pharm. J. 2010, 10, 30-39. [CrossRef] [PubMed] 
231. Calarge, C.A.; Ellingrod, V.L.; Zimmerman, B.; Acion, L.; Sivitz, W.I.; Schlechte, J.A. Leptin gene -2548G/A variants predict risperidone-associated weight gain in children and adolescents. Psychiatr. Genet. 2009, 19, 320-327. [CrossRef] [PubMed]

232. Zhang, X.Y.; Tan, Y.L.; Zhou, D.F.; Haile, C.N.; Cao, L.Y.; Xu, Q.; Shen, Y.; Kosten, T.A.; Kosten, T.R. Association of clozapineinduced weight gain with a polymorphism in the leptin promoter region in patients with chronic schizophrenia in a Chinese population. J. Clin. Psychopharmacol. 2007, 27, 246-251. [CrossRef] [PubMed]

233. Kang, S.G.; Lee, H.J.; Park, Y.M.; Choi, J.E.; Han, C.; Kim, Y.K.; Kim, S.H.; Lee, M.S.; Joe, S.H.; Jung, I.K.; et al. Possible association between the $-2548 \mathrm{~A} / \mathrm{G}$ polymorphism of the leptin gene and olanzapine-induced weight gain. Prog. Neuro Psychopharmacol. Biol. Psychiatry 2008, 32, 160-163. [CrossRef]

234. Gregoor, J.G.; van der Weide, J.; Mulder, H.; Cohen, D.; van Megen, H.J.; Egberts, A.C.; Heerdink, E.R. Polymorphisms of the LEP- and LEPR gene and obesity in patients using antipsychotic medication. J. Clin. Psychopharmacol. 2009, 29, 21-25. [CrossRef] [PubMed]

235. Le Hellard, S.; Theisen, F.M.; Haberhausen, M.; Raeder, M.B.; Fernø, J.; Gebhardt, S.; Hinney, A.; Remschmidt, H.; Krieg, J.C.; Mehler-Wex, C.; et al. Association between the insulin-induced gene 2 (INSIG2) and weight gain in a German sample of antipsychotic-treated schizophrenic patients: Perturbation of SREBP-controlled lipogenesis in drug-related metabolic adverse effects? Mol. Psychiatry 2009, 14, 308-317. [CrossRef] [PubMed]

236. Tiwari, A.K.; Zai, C.C.; Meltzer, H.Y.; Lieberman, J.A.; Muller, D.J.; Kennedy, J.L. Association study of polymorphisms in insulin induced gene 2 (INSIG2) with antipsychotic-induced weight gain in European and African-American schizophrenia patients Hum. Psychopharmacol. 2010, 25, 253-259. [CrossRef]

237. Park, Y.M.; Chung, Y.C.; Lee, S.H.; Lee, K.J.; Kim, H.; Choi, J.E.; Kang, S.G.; Lee, M.S.; Kim, L.; Lee, H.J. G-protein beta3 Subunit Gene 825C/T Polymorphism Is Not Associated with Olanzapine-Induced Weight Gain in Korean Schizophrenic Patients. Psychiatry Investig. 2009, 6, 39-43. [CrossRef]

238. Tsai, S.J.; Yu, Y.W.; Lin, C.H.; Wang, Y.C.; Chen, J.Y.; Hong, C.J. Association study of adrenergic beta3 receptor (Trp64Arg) and G-protein beta3 subunit gene (C825T) polymorphisms and weight change during clozapine treatment. Neuropsychobiology 2004, 50, 37-40. [CrossRef]

239. Bishop, J.R.; Ellingrod, V.L.; Moline, J.; Miller, D. Pilot study of the G-protein beta3 subunit gene (C825T) polymorphism and clinical response to olanzapine or olanzapine-related weight gain in persons with schizophrenia. Med. Sci. Monit. 2006, 12, 47-50.

240. Hong, C.J.; Lin, C.H.; Yu, Y.W.; Chang, S.C.; Wang, S.Y.; Tsai, S.J. Genetic variant of the histamine-1 receptor (glu349asp) and body weight change during clozapine treatment. Psychiatr. Genet. 2002, 12, 169-171. [CrossRef] [PubMed]

241. Tiwari, A.K.; Rodgers, J.B.; Sicard, M.; Zai, C.C.; Likhodi, O.; Freeman, N.; Meltzer, H.Y.; Lieberman, J.A.; Kennedy, J.L.; Müller D.J. Association study of polymorphisms in cholecystokinin gene and its receptors with antipsychotic induced weight gain in schizophrenia patients. Prog. Neuro Psychopharmacol. Biol. Psychiatry 2010, 34, 1484-1490. [CrossRef] [PubMed]

242. Clark, D.; Skrobot, O.A.; Adebiyi, I.; Susce, M.T.; de Leon, J.; Blakemore, A.F.; Arranz, M.J. Apolipoprotein-E gene variants associated with cardiovascular risk factors in antipsychotic recipients. Eur. Psychiatry 2009, 24, 456-463. [CrossRef] [PubMed]

243. Zhang, X.Y.; Zhou, D.F.; Wu, G.Y.; Cao, L.Y.; Tan, Y.L.; Haile, C.N.; Li, J.; Lu, L.; Kosten, T.A.; Kosten, T.R. BDNF levels and genotype are associated with antipsychotic-induced weight gain in patients with chronic schizophrenia. Neuropsychopharmacology 2008, 33, 2200-2205. [CrossRef]

244. Tiwari, A.K.; Zai, C.C.; Likhodi, O.; Lisker, A.; Singh, D.; Souza, R.P.; Batra, P.; Zaidi, S.H.; Chen, S.; Liu, F.; et al. A common polymorphism in the cannabinoid receptor 1 (CNR1) gene is associated with antipsychotic-induced weight gain in Schizophrenia. Neuropsychopharmacology 2010, 35, 1315-1324. [CrossRef] [PubMed]

245. Ellingrod, V.L.; Miller, D.; Schultz, S.K.; Wehring, H.; Arndt, S. CYP2D6 polymorphisms and atypical antipsychotic weight gain. Psychiatr. Genet. 2002, 12, 55-58. [CrossRef] [PubMed]

246. Ellingrod, V.L.; Miller, D.D.; Taylor, S.F.; Moline, J.; Holman, T.; Kerr, J. Metabolic syndrome and insulin resistance in schizophrenia patients receiving antipsychotics genotyped for the methylenetetrahydrofolate reductase (MTHFR) 677C/T and 1298A/C variants. Schizophr. Res. 2008, 98, 47-54. [CrossRef] [PubMed]

247. van Winkel, R.; Rutten, B.P.; Peerbooms, O.; Peuskens, J.; van Os, J.; De Hert, M. MTHFR and risk of metabolic syndrome in patients with schizophrenia. Schizophr. Res. 2010, 121, 193-198. [CrossRef]

248. Herken, H.; Erdal, M.; Aydin, N.; Sengul, C.; Karadag, F.; Barlas, O.; Akin, F. The association of olanzapine-induced weight gain with peroxisome proliferator-activated receptor-gamma2 Pro12Ala polymorphism in patients with schizophrenia. DNA Cell. Biol. 2009, 28, 515-519. [CrossRef]

249. Muller, D.J.; Klempan, T.A.; De Luca, V.; Sicard, T.; Volavka, J.; Czobor, P.; Sheitman, B.B.; Lindenmayer, J.P.; Citrome, L.; McEvoy, J.P.; et al. The SNAP-25 gene may be associated with clinical response and weight gain in antipsychotic treatment of schizophrenia. Neurosci. Lett. 2005, 379, 81-89. [CrossRef]

250. Basile, V.S.; Masellis, M.; McIntyre, R.S.; Meltzer, H.Y.; Lieberman, J.A.; Kennedy, J.L. Genetic dissection of atypical antipsychoticinduced weight gain: Novel preliminary data on the pharmacogenetic puzzle. J. Clin. Psychiatry 2001, 62, 5-66.

251. Wang, Y.C.; Bai, Y.M.; Chen, J.Y.; Lin, C.C.; Lai, I.C.; Liou, Y.J. Genetic association between TNF-alpha -308 G>A polymorphism and longitudinal weight change during clozapine treatment. Hum. Psychopharmacol. 2010, 25, 303-309. [CrossRef]

252. Amar, A.; Segman, R.H.; Shtrussberg, S.; Sherman, L.; Safirman, C.; Lerer, B.; Brautbar, C. An association between clozapineinduced agranulocytosis in schizophrenics and HLA-DQB1*0201. Int. J. Neuropsychopharmacol. 1998, 1, 41-44. [CrossRef] [PubMed] 
253. Valevski, A.; Klein, T.; Gazit, E.; Meged, S.; Stein, D.; Elizur, A.; Narinsky, E.R.; Kutzuk, D.; Weizman, A. HLA-B38 and clozapine-induced agranulocytosis in Israeli Jewish schizophrenic patients. Eur. J. Immunogenet. 1998, 25, 11-13. [CrossRef]

254. Dettling, M.; Schaub, R.T.; Mueller-Oerlinghausen, B.; Roots, I.; Cascorbi, I. Further evidence of human leukocyte antigen-encoded susceptibility to clozapine-induced agranulocytosis independent of ancestry. Pharmacogenetics 2001, 11, 135-141. [CrossRef] [PubMed]

255. Saito, T.; Ikeda, M.; Mushiroda, T.; Ozeki, T.; Kondo, K.; Shimasaki, A.; Kawase, K.; Hashimoto, S.; Yamamori, H.; Yasuda, Y.; et al. Pharmacogenomic Study of Clozapine-Induced Agranulocytosis/Granulocytopenia in a Japanese Population. Biol. Psychiatry 2016, 80, 636-642. [CrossRef] [PubMed]

256. Ostrousky, O.; Meged, S.; Loewenthal, R.; Valevski, A.; Weizman, A.; Carp, H.; Gazit, E. NQO2 gene is associated with clozapine-induced agranulocytosis. Tissue Antigens 2003, 62, 483-491. [CrossRef]

257. Mosyagin, I.; Dettling, M.; Roots, I.; Mueller-Oerlinghausen, B.; Cascorbi, I. Impact of myeloperoxidase and NADPH-oxidase polymorphisms in drug-induced agranulocytosis. J. Clin. Psychopharmacol. 2004, 24, 613-617. [CrossRef] [PubMed]

258. Dettling, M.; Sachse, C.; Muller-Oerlinghausen, B.; Roots, I.; Brockmoller, J.; Rolfs, A.; Cascorbi, I. Clozapine-induced agranulocytosis and hereditary polymorphisms of clozapine metabolizing enzymes: No association with myeloperoxidase and cytochrome P4502D6. Pharmacopsychiatry 2000, 33, 218-220. [CrossRef]

259. Turbay, D.; Lieberman, J.; Alper, C.A.; Delgado, J.C.; Corzo, D.; Yunis, J.J.; Yunis, E.J. Tumor necrosis factor constellation polymorphism and clozapine-induced agranulocytosis in two different ethnic groups. Blood 1997, 89, 4167-4174. [CrossRef]

260. Musil, R.; Spellmann, I. Pharmacogenetics and cognitive symptoms in schizophrenia patients treated with antipsychotics. Pharmacogenomics 2018, 19, 927-930. [CrossRef]

261. Aberg, K.; Adkins, D.E.; Bukszar, J.; Webb, B.T.; Caroff, S.N.; Miller, D.D.; Sebat, J.; Stroup, S.; Fanous, A.H.; Vladimirov, V.I.; et al. Genomewide association study of movement-related adverse antipsychotic effects. Biol. Psychiatry. 2010, 67, 279-282. [CrossRef]

262. Adkins, D.E.; Aberg, K.; McClay, J.L.; Bukszár, J.; Zhao, Z.; Jia, P.; Stroup, T.S.; Perkins, D.; McEvoy, J.P.; Lieberman, J.A.; et al. Genomewide pharmacogenomic study of metabolic side effects to antipsychotic drugs. Mol. Psychiatry 2011, 16, 321-332. [CrossRef] [PubMed]

263. Alkelai, A.; Greenbaum, L.; Rigbi, A.; Kanyas, K.; Lerer, B. Genome-wide association study of antipsychotic-induced parkinsonism severity among schizophrenia patients. Psychopharmacology 2009, 206, 491-499. [CrossRef] [PubMed]

264. Hermes, E.; Nasrallah, H.; Davis, V.; Meyer, J.; McEvoy, J.; Goff, D.; Davis, S.; Stroup, T.S.; Swartz, M.; Lieberman, J.; et al. The association between weight change and symptom reduction in the CATIE schizophrenia trial. Schizophr. Res. 2011, 128, 166-170. [CrossRef] [PubMed]

265. McClay, J.L.; Adkins, D.E.; Aberg, K.; Bukszar, J.; Khachane, A.N.; Keefe, R.S.; Perkins, D.O.; McEvoy, J.P.; Stroup, T.S.; Vann, R.E.; et al. Genome-wide pharmacogenomic study of neurocognition as an indicator of antipsychotic treatment response in schizophrenia. Neuropsychopharmacology 2011, 36, 616-626. [CrossRef]

266. Chagnon, Y.C.; Merette, C.; Bouchard, R.H.; Emond, C.; Roy, M.A.; Maziade, M. A genome wide linkage study of obesity as secondary effect of antipsychotics in multigenerational families of eastern Quebec affected by psychoses. Mol. Psychiatry 2004, 9, 1067-1074. [CrossRef] [PubMed]

267. Inada, T.; Koga, M.; Ishiguro, H.; Horiuchi, Y.; Syu, A.; Yoshio, T.; Takahashi, N.; Ozaki, N.; Arinami, T. Pathway-based association analysis of genome-wide screening data suggest that genes associated with the gamma-aminobutyric acid receptor signaling pathway are involved in neuroleptic-induced, treatment-resistant tardive dyskinesia. Pharm. Genom. 2008, 18, 317-323. [CrossRef]

268. Zhang, J.P.; Robinson, D.; Yu, J.; Gallego, J.; Fleischhacker, W.W.; Kahn, R.S.; Crespo-Facorro, B.; Vazquez-Bourgon, J.; Kane, J.M.; Malhotra, A.K.; et al. Schizophrenia Polygenic Risk Score as a Predictor of Antipsychotic Efficacy in First-Episode Psychosis. Am. J. Psychiatry 2018, 176, 21-28. [CrossRef] 